


\section{Economische waarde en toekomstperspectief van de IJsselmeervisserij}

Wim Zaalmink en Bea Deetman 
Wim Zaalmink en Bea Deetman o, 2021. Economische waarde en toekomstperspectief van de IJsselmeervisserij. Wageningen, Wageningen Economic Research, Rapport 2021-029. 46 blz.; 16 fig.; 20 tab. ; 7 ref.

Dit rapport beschrijft de vangsten en economische waarde van de IJsselmeervisserij van 2015 tot en met 2020. Ook wordt inzicht gegeven in de vangsten per vistuig en de waarde van de verschillende visrechten. Door interviews met vissers is informatie verkregen over de opvolgingssituatie en de continuïteit van visserijbedrijven. Ook is inzicht verkregen in de belangstelling voor vrijwillige verkoop van visrechten en de kosten ervan. De totale waarde van vangsten van de IJsselmeervisserij is sinds het jaar 2013 toegenomen van 3,1 mln. euro naar 6,2 mln. euro in 2019. Het grootste deel van deze waarde bestaat uit snoekbaars en aal. De vrije marktwaarde van de totale visserij bedraagt circa $18 \mathrm{mln}$. euro, opgebouwd uit 7,3 $\mathrm{mln}$. euro voor schubvisrechten en 10,6 mln. euro voor aalvisrechten. Er zijn 39 visserijbedrijven, waarvan 31 bedrijven economisch afhankelijk zijn van de visserij. Op circa een derde van de bedrijven is geen opvolger aanwezig.

This report describes the catches and economic value of the IJsselmeer fishery sector from 2015 to 2020, and provides insight into the catches per fishing gear and the value of the various fishing rights. Information on the succession situation and fishing company continuity was obtained via interviews with fishermen. Insight was also obtained into the level of interest in the voluntary sale of fishing rights and the costs of this. The IJsselmeer fishery sector total catch value has increased from 3.1 million euro in 2013 to 6.2 million euro in 2019. Most of this value relates to pike perch and eel. The free market value of the total fishery sector amounts to approximately 18 million euro, of which 7.3 million euro is for scale fish fishing rights and 10.6 million euro is for eel fishing rights. There are 39 fishing companies, of which 31 companies depend economically on fishing. No successor is available for approximately a third of the companies.

Trefwoorden: IJsselmeervisserij, visrechten, vistuigen, vergunningen, toegevoegde waarde, continuïteit bedrijven, opvolging

Dit rapport is gratis te downloaden op https://doi.org/10.18174/543109 of op www. wur. nl/economicresearch (onder Wageningen Economic Research publicaties).

(C) 2021 Wageningen Economic Research

Postbus 29703, 2502 LS Den Haag, T 07033583 30, E communications.ssg@wur.nl, www. wur. nl/economic-research. Wageningen Economic Research is onderdeel van Wageningen University \& Research.

\section{(cc) BY-NC}

Dit werk valt onder een Creative Commons Naamsvermelding-Niet Commercieel 4.0 Internationaallicentie.

(C) Wageningen Economic Research, onderdeel van Stichting Wageningen Research, 2021 De gebruiker mag het werk kopiëren, verspreiden en doorgeven en afgeleide werken maken. Materiaal van derden waarvan in het werk gebruik is gemaakt en waarop intellectuele eigendomsrechten berusten, mogen niet zonder voorafgaande toestemming van derden gebruikt worden. De gebruiker dient bij het werk de door de maker of de licentiegever aangegeven naam te vermelden, maar niet zodanig dat de indruk gewekt wordt dat zij daarmee instemmen met het werk van de gebruiker of het gebruik van het werk. De gebruiker mag het werk niet voor commerciële doeleinden gebruiken.

Wageningen Economic Research aanvaardt geen aansprakelijkheid voor eventuele schade voortvloeiend uit het gebruik van de resultaten van dit onderzoek of de toepassing van de adviezen.

Wageningen Economic Research is ISO 9001:2015 gecertificeerd.

Wageningen Economic Research Rapport 2021-029 | Projectcode 2282300466

Foto omslag: Wim Zaalmink/Wageningen University \& Research 


\section{Inhoud}

Woord vooraf $\quad 5$

Samenvatting $\quad 6$

$\begin{array}{lll}\text { S.1 Belangrijkste uitkomsten } & 6\end{array}$

$\begin{array}{lll}\text { S.2 Overige uitkomsten } & 7\end{array}$

$\begin{array}{lll}\text { S.3 Methode } & 8\end{array}$

Summary $\quad 9$

$\begin{array}{llr}\text { S.1 Key findings } & 9\end{array}$

S.2 Complementary findings $\quad 10$

$\begin{array}{ll}\text { S.3 Method } & 11\end{array}$

$\begin{array}{lr}1 & 12\end{array}$

$1.1 \quad$ Huidige situatie en aanleiding $\quad 12$

$\begin{array}{lll}1.2 & \text { Probleemstelling } & 13\end{array}$

1.3 Doel 14

1.4 Opbouw van het rapport $\quad 14$

$2 \quad$ Vissers, bedrijven, vangsten en opbrengsten $\quad 15$

2.1 Bronnen 15

2.1.1 Gegevensbestanden 15

2.1.2 Gesprekken met vissers en andere betrokkenen $\quad 15$

2.2 Aanlandingen 16

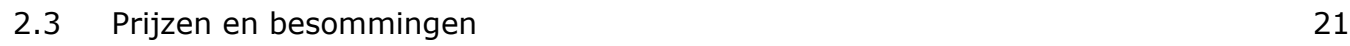

$\begin{array}{lll}2.4 & \text { Bedrijven en vergunningen } & 22\end{array}$

2.5 Besomming per visser en bedrijfstype $\quad 23$

$2.6 \quad$ Nadere typering van bedrijven en vissers $\quad 24$

$\begin{array}{lll}2.7 & \text { Schepen } & 26\end{array}$

$\begin{array}{lll}3 & \text { Waarde van visrechten en vistuigen } & 27\end{array}$

$\begin{array}{ll}3.1 & \text { Aantallen merkjes en rechten }\end{array}$

$\begin{array}{lll}3.2 & \text { Schubvistuigen } & 28\end{array}$

$\begin{array}{lll}3.3 & \text { Aalvistuigen } & 28\end{array}$

3.4 Totale vangsten per vistuig en waarde per vistuig $\quad 29$

3.5 Waarde van rechten en kosten van vrijwillige uitkoop 31

4 Herstructurering: mogelijkheden en kosten 33

$4.1 \quad$ Interesse uitkoopregeling $\quad 33$

4.2 Kosten van vrijwillige uitkoop $\quad 34$

$\begin{array}{lll}4.3 & \text { Mogelijkheden voor flankerend beleid } & 35\end{array}$

4.4 Aanvullende maatregelen voor visserijreductie en kosten ervan 36

$\begin{array}{llr}5 & \text { Discussie } & 38\end{array}$

$\begin{array}{llr}6 & \text { Conclusies } & 39\end{array}$

$\begin{array}{ll}\text { Literatuur en websites } & 41\end{array}$

Bijlage 1 Gesprekslijst IJsselmeervissers $\quad 42$ 



\section{Woord vooraf}

Er wordt al lang gesproken over een herstructurering van de IJsselmeervisserij. In 2018 is tussen de verantwoordelijke bestuurlijke partijen een akkoord bereikt over een stip op de horizon: een economisch rendabele en duurzame beroepsvisserij met een vangstcapaciteit die passend is bij ontwikkelingen in draagkracht van het watersysteem IJsselmeer - Markermeer - IJmeer. Bij de herstructurering is het belangrijk om te weten wat de economische waarde is van de visserij, maar ook welke mogelijkheden en onmogelijkheden IJsselmeervissers zien voor hun bedrijf voor de toekomst.

Het ministerie van Landbouw, Natuur en Voedselkwaliteit (LNV) heeft aan Wageningen Economic Research gevraagd inzicht te geven in de economische waarde van de IJsselmeervisserij en de waarde van visrechten, en hoe vissers tegen hun toekomst en een eventuele vrijwillige uitkoop aankijken. Naast data-analyse zijn alle IJsselmeervissers uitgenodigd voor een gesprek aan de hand van een vooraf afgestemde vragenlijst.

De gesprekken waren veelal openhartig en soms emotioneel. Wij beseffen dat de discussie over de herstructurering veel zorgen teweegbrengt en waarderen het des te meer dat zulke open gesprekken mogelijk waren. We hopen dat we met de opgedane informatie een goede analyse hebben kunnen uitvoeren die voldoet aan de wensen van alle betrokkenen.

Het onderzoek is uitgevoerd door Bea Deetman en Wim Zaalmink (projectleider). Daarnaast heeft Linda Puister een deel van de data-analyse uitgevoerd. De betrokken onderzoekers willen alle geïnterviewden hartelijk bedanken voor hun tijd, en in het bijzonder de IJsselmeervissers.

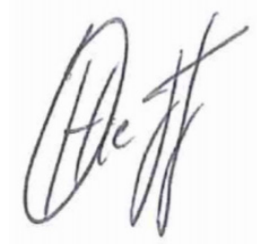

Ir. O. (Olaf) Hietbrink

Business Unit Manager Wageningen Economic Research

Wageningen University \& Research 


\section{Samenvatting}

\section{S.1 Belangrijkste uitkomsten}

Dit project is uitgevoerd in het kader van het Actieplan toekomstbestendig visserijbeheer IJsselmeergebied. Doel van dit actieplan is te komen tot een toekomstbestendige duurzame visserij . Belangrijke pijlers uit dit actieplan zijn:

1. Het komen tot een gezamenlijk inzicht in de benodigde omvang van de commerciële visbestanden en hun natuurlijke aanwas zodat deze duurzaam geoogst kan worden.

2. Een beheersysteem en -stelsel dat gericht is op het verduurzamen van de visserij.

3. Herstructurering van de visserij om te komen tot een vangstcapaciteit die past bij een duurzame visserij.

Met dit project wordt bijgedragen aan pijler 3, met een extra focus op schubvis en de bijbehorende vistuigen. De bijdrage van dit project is verwoord in de volgende doelstellingen:

1. het vaststellen van de economische waarde van de IJsselmeervisserij en daaraan gekoppelde opkoopwaarde van de verschillende vistuigen.

2. het in beeld brengen van het toekomstperspectief in het licht van de ontwikkelingen van de voorbije jaren en in het bijzonder de herstructurering (vissers, visserijbedrijven, leeftijd ondernemers, opvolgingssituatie en toekomstperspectief).

3. inzicht geven in vrijwillige uitkoopmogelijkheden en kosten ervan, mogelijkheden voor sociaal flankerende maatregelen en in kosten van aanvullende maatregelen.

De vangsten (totale aanlandingen) van de IJsselmeervisserij nemen de laatste jaren sterk toe (figuur S.1). De totale waarde van de aanlandingen (besomming) van de IJsselmeervisserij is sinds het jaar 2013 toegenomen van 3,1 mln. euro naar 6,2 mln. euro in 2019 (figuur S.2). In dit laatste jaar bestond het grootste deel van deze waarde uit snoekbaars (44\%) en aal (41\%), gevolgd door wolhandkrab (8\%). Van de totale waarde van de vangsten in 2019 (6,2 mln. euro) werd 38\% gerealiseerd door staande netten. De grote (paling)fuiken zorgden voor $36 \%$ van de waarde. Op basis van de totale waarde bedraagt de vrije marktwaarde (waarde van de gehele IJsselmeervisserij bij vrijwillige verkoop) circa $18 \mathrm{mln}$. euro, opgebouwd uit 7,3 mln. euro voor schubvisrechten (zegen en staande netten) en 10,6 mln. euro voor aalvisrechten.

Er zijn 39 visserijbedrijven voor de IJsselmeervisserij. Hiervan zijn 31 bedrijven economisch afhankelijk van de visserij op het IJsselmeer; de overige bedrijven halen de inkomsten vooral buiten de visserij of visserij wordt als hobby uitgeoefend. In totaal zijn naar schatting 63 gezinnen afhankelijk van de IJsselmeervisserij.

Op circa een derde van de bedrijven is geen opvolger aanwezig. Deze bedrijven zullen tussen nu en 15 jaar verdwijnen als er zich geen opvolger aandient of ze worden opgekocht door andere bedrijven. Deze situatie is niet wezenlijk verschillend van de opvolgingssituatie in de landbouw. Bijna alle bedrijven hebben drie jaren met goede omzetten achter de rug en hebben daardoor vertrouwen in de toekomst van het bedrijf. Verder hebben de huidige bedrijven de herstructureringen uit het verleden aan zich voorbij laten gaan en zijn ze niet ingegaan op een goed bod voor hun bedrijf door de grote ondernemingen.

Er is bij IJsselmeervissers weinig animo voor vrijwillige opkoop. Maximaal 7 ondernemers zullen, wanneer er op korte termijn (binnen drie jaar) een vrijwillige regeling komt, nadenken om hun rechten te verkopen. In totaal hebben deze bedrijven 5 certificaten voor staande netten $(=6 \%$ van het totaal), 80 grote fuiken $(=5 \%)$ en 3 hoekwantvergunningen ( $=8 \%$ van het totaal). De vrije marktwaarde van deze bedrijven, gebaseerd op de besommingen tijdens de periode 2015 tot en met 2019, bedraagt bijna 1,1 mln. euro. 
Het merendeel van de vissers wil het bedrijf niet verkopen. Zij kennen een lange familietraditie en hebben vanuit het verleden geleerd te overleven in slechte tijden. Ook zien op dit moment de meeste vissers de noodzaak tot vermindering van de visserijdruk niet, zeker omdat zij ervaren dat de vangsten van snoekbaars de afgelopen jaren sterk zijn toegenomen.

Aanvullend zullen circa 8 vissers op langere termijn ( 3 tot 10 jaar) gebruik willen maken van een vrijwillige uitkoopregeling. De vrije marktwaarde van deze bedrijven bedraagt nu circa 2,3 mln. euro.

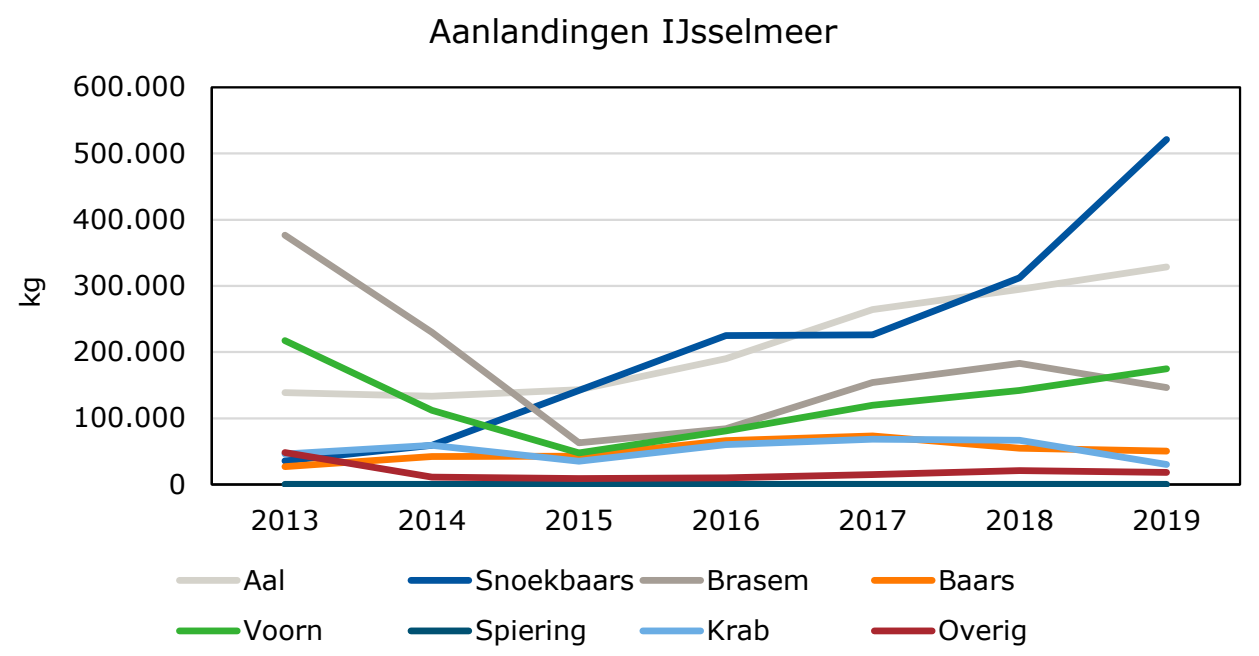

Figuur S.1 Totale aanlandingen (kg) IJsselmeervisserij, 2013 tot en met 2019

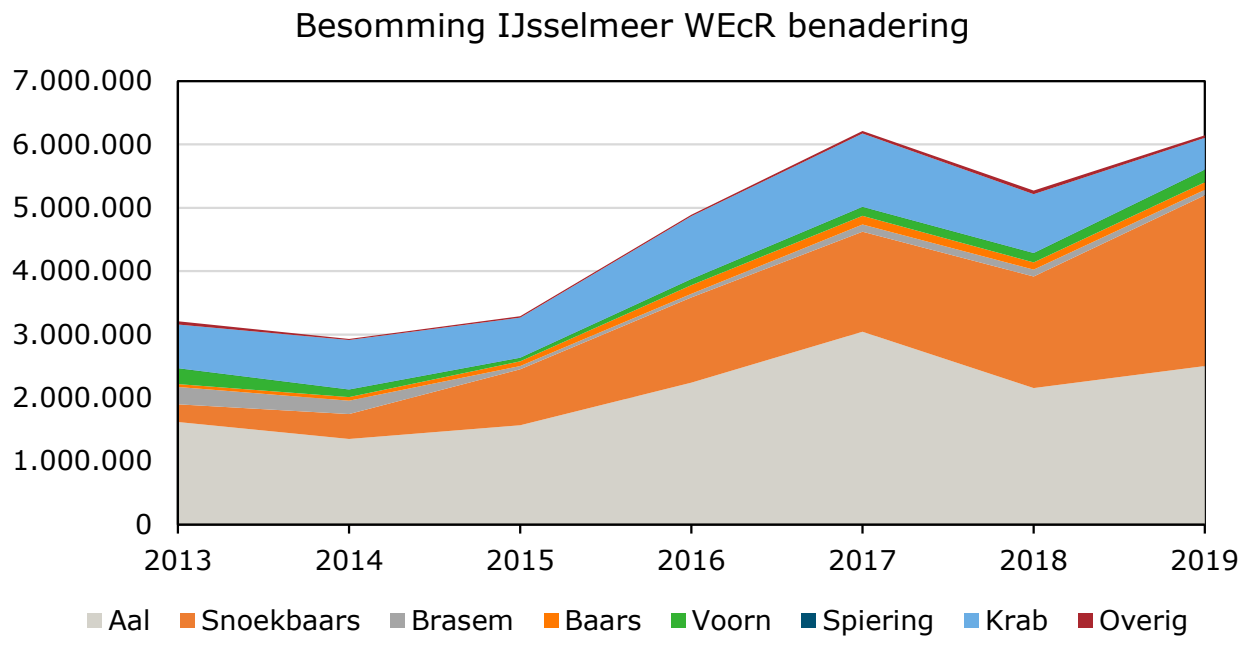

Figuur S.2 Totale besomming (waarde van de aanlandingen in euro) IJsselmeervisserij, 2013 tot en met 2019

\section{S.2 Overige uitkomsten}

De IJsselmeervisserijbedrijven zijn gevestigd in de visserijgemeenschappen die van oudsher bestaan rondom het IJsselmeergebied: Urk, rond de randmeren, Friesland en Noord-Holland. Veelal zijn de bedrijven kleinschalig, wat betekent dat het bedrijf in handen is van één of enkele ondernemers die soms met behulp van familie en/of vrienden het bedrijf runnen. Er zijn twee bedrijven met meer dan 3 vissers. De rechten zijn niet evenredig verdeeld over de bedrijven. Voor de staande netten heeft $13 \%$ van de bedrijven $60 \%$ van de rechten in gebruik. 
Iets meer dan één derde van de bedrijven voert naast de visserij ook andere werkzaamheden op het water uit of heeft er in het verleden ervaring mee opgedaan. Hierbij valt te denken aan monitoringsonderzoek, het maaien van waterplanten en educatieve activiteiten.

Vier bedrijven werken aan ketenverkorting: het gaat hierbij om activiteiten in de handel, het zelf verwerken van vis en het runnen van viswinkels en viskramen.

\section{S.3 Methode}

Voor de actualisatie van de economische waarde van de IJsselmeervisserij zijn vangst- en verkoopgegevens vanuit diverse bronnen verzameld. Door combinatie van deze gegevensbronnen, gesprekken met vissers en - voor enkele vissoorten - expert judgement van onderzoekers, zijn de totale vangsten uit het IJsselmeer en de waarde van deze vangsten berekend. In combinatie met gegevens over de vistuigen die worden gebruikt op het IJsselmeer is de vrije marktwaarde van de verschillende vistuigen berekend.

Er zijn bovendien gesprekken gevoerd met IJsselmeervissers om inzicht te krijgen in de volgende zaken:

- het toekomstperspectief dat vissers voor zichzelf zien;

- de belangstelling voor vrijwillige uitkoopmogelijkheden op korte en langere termijn;

- belangstelling voor sociaal flankerende maatregelen.

Alle vissers zijn benaderd; in totaal zijn 37 gesprekken gevoerd met één of twee ondernemers per bedrijf. Van twee bedrijven is geen ondernemer gesproken. 


\section{Summary}

\section{S.1 Key findings}

This project was implemented in the context of the IJsselmeer Area Future-Proof Fisheries Management Action Plan. The objective of this action plan is to achieve a sustainable and future-proof fishing sector. Important pillars from the action plan are:

1. Achieving joint insight into the size and natural increase rate of commercial fish stocks required to ensure sustainable fishing.

2. A management system and framework that focuses on sustainable fishing.

3. Fisheries restructuring to achieve a catch capacity that results in sustainable fishing.

This project contributes to pillar 3, with an additional focus on scale fish and associated fishing gear. The project contributions are described in the following objectives:

- determining the economic value of the IJsselmeer fishing sector and the buy-back value of the various fishing gear.

- map out the fishing sector's future prospects in the context of recent developments, particularly the restructuring (fishermen, fishing companies, age of entrepreneurs, succession situation and future prospects).

- provide insight into the voluntary buy-out options and their costs, possibilities for social support measures and the costs of any additional measures.

Total IJsselmeer fishing sector catches (landings) have increased significantly in recent years (figure S.1). The IJsselmeer fishing sector total landing value has increased from 3.1 million euro in 2013 to 6.2 million euro in 2019 (figure S.2). In this last year, most of this value comprised pike perch (44\%) and eel (41\%), followed by Chinese mitten crab ( $8 \%)$. Of the total value of IJsselmeer catches in 2019 (6.2 million euro) 38\% were obtained via standing nets. Large eel traps and other traps generated $36 \%$ of the total value.

Based on the total value, the free market value (value of the entire IJsselmeer fishing sector in a voluntary sale) amounts to approximately 18 million euro, of which 7.3 million euro is for scale fish fishing rights (seines and standing nets) and 10.6 million euro is for eel fishing rights.

There are 39 fishing companies in the IJsselmeer fishing sector. 31 of these companies depend economically on the IJsselmeer fishing sector; the other companies obtain income mainly outside the fishing sector or pursue fishing a hobby. An estimated 63 families depend on IJsselmeer fisheries.

No successor is available for approximately a third of the companies. These companies will disappear within 15 years if no successor comes forward or they will be bought out by other companies. This situation is very similar to the succession situation in agriculture. Almost all companies have three years of good turnover behind them and are therefore confident about their company's future. The current companies did not take part in previous restructuring programmes and did not accept good offers for their companies from larger companies.

There is little enthusiasm for voluntary sale among IJsselmeer fishermen. No more than seven entrepreneurs will, if a voluntary regulation is established in the short term (within three years), consider selling their rights. In total, these companies have five certificates for standing nets $(=6 \%$ of the total), 80 large traps $(=5 \%)$ and three longline permits (= $8 \%$ of the total). The free market value of these companies, based on results during the 2015 to 2019 period, amounts to almost 1.1 million euro.

The majority of the fishermen do not want to sell their company. They come from a long family tradition and have learned to survive in difficult times. Most fishermen do not currently see the need 
for reduced fishing intensity, certainly as they have experienced significant increases in pike perch catches in recent years.

In addition, approximately eight fishermen aim to use a voluntary buy-out scheme in the longer term (three to ten years). The free market value of these companies currently amounts to 2.3 million euro.

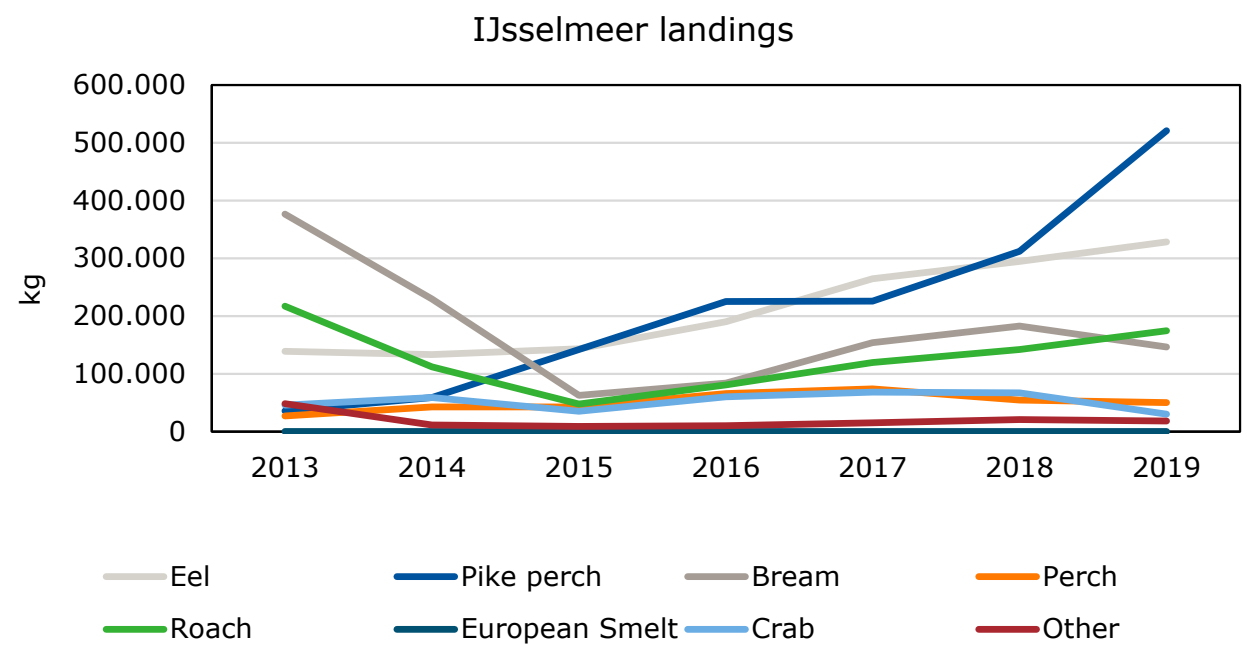

Figure S.1 Total landings (kg) IJsselmeer fishing sector, 2013 to 2019 inclusive

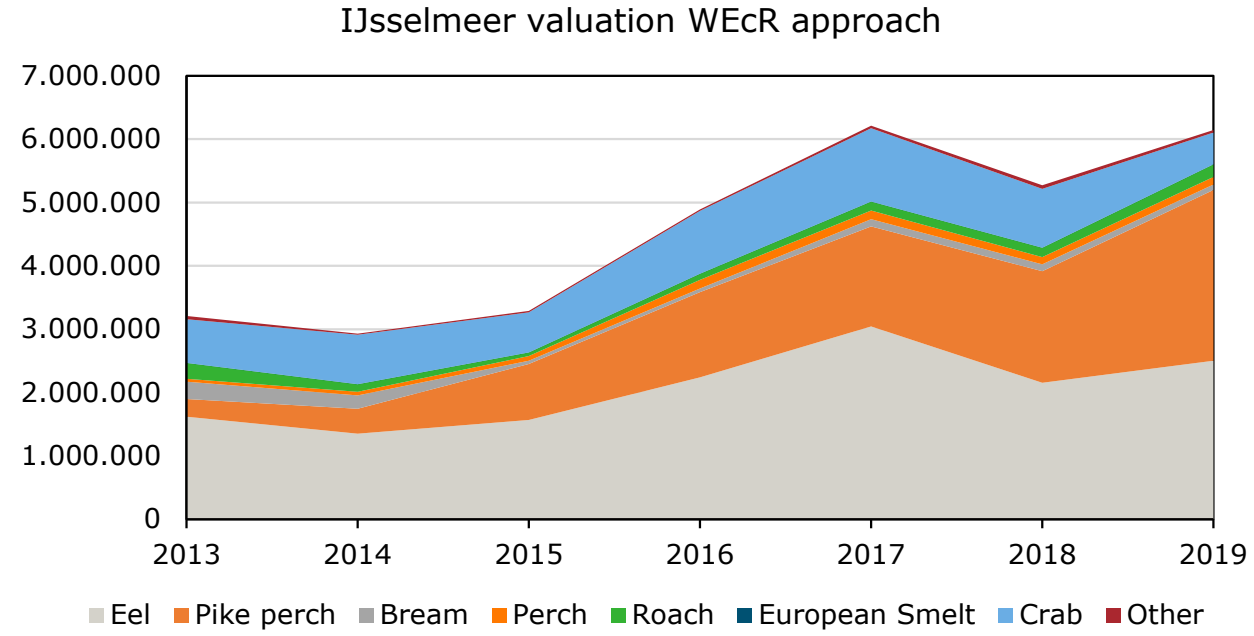

Figure S.2 Total valuation (value of landings in euro) of IJsselmeer fishing sector, 2013 to 2019 inclusive

\section{S.2 Complementary findings}

The IJsselmeer fishing companies are located in the fishing communities that traditionally existed around the IJsselmeer area: Urk, around the Randmeren (bordering lakes of Flevoland), Friesland and North Holland. The companies are mostly small-scale, which means that the company is owned by one or some entrepreneurs, sometimes running the company with the help of family and/or friends. There are two companies with more than three fishermen. The rights are not distributed evenly across the companies. For the standing nets, $13 \%$ of companies account for $60 \%$ of the rights being used. 
Slightly over a third of companies also carry out other water-based activities than fishing or has done so in the past. This includes monitoring surveys, water plant cutting and educational activities.

Four companies are working on shortening the chain, including trader activities, fish processing and operating as fishmongers or running market stalls.

\section{S.3 Method}

Catch and sales data were collected from various sources to provide an update on the economic value of the IJsselmeer fishing sector. Interviews with fishermen and, for a few types of fish, the expert opinion of research associates were combined to calculate the total IJsselmeer catch and the value of these catches. In combination with data about the fishing gear used on the IJsselmeer, a calculation was also made of the free market value of the various fishing gear.

Besides, interviews were carried out with IJsselmeer fishermen to gain insight into the following:

- the future prospects envisaged by the fishermen themselves;

- their interest in voluntary buy-out options in the short and longer term;

- their interest in social support measures.

All fishermen were approached and a total of 37 interviews were conducted with one or two entrepreneurs per company. No entrepreneur was interviewed in two companies. 


\section{$1 \quad$ Inleiding}

\subsection{Huidige situatie en aanleiding}

De visserij op het IJsselmeer, Markermeer en IJmeer (hierna IJsselmeervisserij genoemd) is voor een aantal visserij ondernemers een belangrijke bron van inkomsten. Het ministerie van Landbouw, Natuur en Voedselkwaliteit (LNV) is verantwoordelijk voor de regulering van de visserij op de genoemde meren. Schubvis zoals snoekbaars, baars, voorn en brasem zijn naast paling en wolhandkrab commercieel belangrijke vissoorten. Het ministerie heeft samen met andere partijen doelstellingen benoemd voor een duurzame visserij. Hierbij zijn visserijwetgeving, KRW-maatstaven en Natura 2000-doelstellingen maatgevend. In het synthesedocument Toekomstbeeld visstand IJsselmeer/Markermeer (bijlage bij brief van ministerie van LNV aan Provincie Friesland, 23 januari 2017) wordt het gewenste toekomstbeeld geschetst op basis van de verplichtingen die volgen uit de Visserijwet en de EU Kaderrichtlijn Water. In het document wordt voorgesteld om:

'voor de vier commercieel beviste vissoorten een situatie na te streven waarbij binnen de geschetste termijn van circa 15 jaar wordt toegewerkt naar een situatie waarbij sprake is van een evenwichtiger lengte-opbouw van de bestanden met meer grotere exemplaren en een groter aantal jaarklassen. Met de sturing hierop wordt tegelijk gerealiseerd dat wordt toegewerkt naar een toename van de (paai)bestanden en zal sprake zijn van een natuurlijker opbouw en samenstelling van de visstand. Hiermee wordt een stap gezet van de huidige behoudsdoelstellingen, naar een inzet gericht op een herstel van de situatie met een visstand met een omvang en samenstelling die past bij de draagkracht van het systeem.'

Om dit te bereiken is in 2019 een gezamenlijk Actieplan (Kamerbrief over investeringen in verduurzaming IJsselmeervisserij, 25 maart 2019) opgesteld door de volgende partijen: de Producentenorganisatie IJsselmeer (PO), Vogelbescherming Nederland (VBN), Sportvisserij Nederland (SVN), coalitie Blauwe Hart Natuurlijk (BHN), de provincies Fryslân, Flevoland en Noord-Holland en de ministeries van LNV en I\&W (Rijkswaterstaat). In dit actieplan is overeenstemming bereikt over een stip op de horizon: een economisch rendabele en duurzame beroepsvisserij met een vangstcapaciteit die passend is bij de ontwikkelingen in draagkracht van het IJsselmeergebied. In dit actieplan is gedefinieerd dat gestreefd wordt naar een visserij die past bij de draagkracht van het systeem. Een van de onderdelen daarbij is een herstructurering om te komen tot een vangstcapaciteit die past bij een duurzame visserij.

Het IJsselmeergebied is het grootste aaneengesloten zoetwatermeer van West-Europa, en heeft een grote landschappelijke en cultuurhistorische waarde. Het gebied is ook sinds december 2009 aangewezen als Natura 2000-gebied (rwsnatura2000.nl). Voor de waterkwaliteit zijn beoordelingscriteria vastgesteld onder de Kaderrichtlijn Water. Een transitie naar een visserij die in balans is met de vereisten voor natuur- en waterkwaliteit is een belangrijke pijler uit het Actieplan Toekomstbestendig Visserijbeheer. De focus ligt daarbij op de schubvissoorten snoekbaars, baars, blankvoorn en brasem. Voor natuurherstel en voor een duurzame visserij moeten de bestanden hiervan herstellen.

Vanuit de Kaderrichtlijn Water worden eisen gesteld aan de ecologische kwaliteit van het water, inclusief de visbestanden en de samenstelling van deze bestanden. In opdracht van het ministerie van LNV adviseert WMR over de jaarlijkse hoeveelheid in het IJsselmeergebied door visserij te onttrekken vis. Basis voor dit advies is een continue monitoring van de visbestanden. Om te voldoen aan de KRWeisen is uit onderzoek gebleken dat aanzienlijke reducties van de visserij-inspanning noodzakelijk zijn om de schubvisbestanden (met name brasem en blankvoorn, gevolgd door baars en snoekbaars) te herstellen naar niveaus die voldoen aan de eisen (Tien et al., 2020). 
Daarnaast speelt dat ook Natura 2000 eisen stelt, met name vanuit de vogelbescherming. Dit houdt in dat er voldoende voedsel (vis) voor vogels beschikbaar moet zijn en dat 'vogel beschermende' maatregelen getroffen moeten worden om vogelsterfte zo veel mogelijk te voorkomen. Voor de visserij zijn dit dus aanvullende beperkingen naast de maatregelen die vanuit de visserijwet genomen zijn.

De overheidspartijen hebben in totaal 9,2 mln. euro beschikbaar gesteld voor de herstructurering van de visserij. Dit geld kan onder andere worden besteed aan vermindering van de visserijcapaciteit via vrijwillige uitkoop.

\subsection{Probleemstelling}

In het Actieplan toekomstbestendig visserijbeheer IJsselmeergebied wordt een eindbeeld geschetst van een duurzame visserij, waarbij de vangstcapaciteit in het IJsselmeer is afgestemd op de hoeveelheid verantwoord te onttrekken vis. Dit betekent dat op termijn visbestanden qua omvang, samenstelling en populatieopbouw passen bij de draagkracht van het ecosysteem.

Dit eindbeeld is vertaald in een drie beheerdoelstellingen:

1. maximale duurzame commerciële vangsten met

2. meer grote vis, zoals gevraagd vanuit de Kaderrichtlijn Water en

3. voedselreservering voor de potentie aan vogels, zoals omschreven in de Natura 2000doelstellingen.

Om deze doelstellingen te realiseren, is een herstructurering van de IJsselmeervisserij voorzien. Uit een studie van WMR (Tien et al., 2020) blijkt dat een aanzienlijke vangstreductie gewenst is in kader van de beheerdoelstellingen voor 2027.

In het seizoen $2014 / 2015$ is al een aantal maatregelen genomen om de visserijdruk te verminderen. De belangrijkste maatregel bestond toen uit een reductie van $85 \%$ van het aantal toegestane staande netten. Door deze maatregel mochten per certificaat van 50 netten 8 netten worden ingezet door vissers. WMR concludeert dat er sinds 2015 geen verdere achteruitgang van de vier bestanden heeft plaatsgevonden, maar ook dat er geen consistente signalen zijn voor herstel. Alleen voor snoekbaars is de situatie positief; het paaibestand neemt consistent toe sinds 2015 en deze toename betreft meerdere leeftijdscategorieën. Voor herstel van het snoekbaarsbestand mag van deze soort vanaf 2023/2024 of vanaf het moment dat wet- en regelgeving zijn aangepast, per visseizoen maximaal 110 ton worden gevangen (Kamerbrief 6 oktober 2020 Voortgang Actieplan Toekomstbestendig visserijbeheer IJsselmeergebied, 2020), een lagere hoeveelheid dan momenteel wordt gevangen.

Deze maximale vangsthoeveelheid zorgt ervoor dat maatregelen noodzakelijk zijn. In het Actieplan wordt een herstructurering als een van de maatregelen genoemd. Hiervoor is een fonds van 9,2 mln. beschikbaar voor vrijwillige uitkoop van visrechten en flankerend beleid voor stoppende IJsselmeervissers.

Voor een (vrijwillige) uitkoop van rechten is inzicht in de waarde van rechten van belang. Deze waarde in de vrije markt is de verwachtingswaarde van de toekomstige verdiensten van de vangsten die gedaan kunnen worden op basis van deze rechten. Hiervoor is het belangrijk te weten wat in het verleden de verdiensten zijn geweest. Daarnaast is kennis van de huidige IJsselmeervisserijbedrijven en de visie van deze ondernemers op de herstructureringsplannen nodig.

De eerste vraag daarbij is welke economische waarde de IJsselmeervisserij heeft, en hoeveel vissers er hun brood mee verdienen. In het jaar 2016 is door Wageningen Economic Research een studie uitgevoerd naar de economische waarde IJsselmeervisserij. In deze studie zijn de aanlandingen en besommingen van IJsselmeervissers berekend, en de vangsten met de verschillende vistuigen. Hierbij zijn alle commerciële visserijsoorten onderzocht, dus paling, schubvis (snoekbaars, baars, voorn en brasem) en wolhandkrab. Sinds 2016 zijn de vangsten en besommingen van sommige soorten fors toegenomen, andere soorten zijn gelijk gebleven of verminderd. Hiermee is naar alle 
waarschijnlijkheid ook de economische waarde gewijzigd, die een rol speelt bij de herstructurering. Een actualisering van de studie bleek dus noodzakelijk.

De tweede vraag is hoe de sector eruitziet: hoeveel bedrijven zijn er, hoe groot zijn de bedrijven, hoe afhankelijk zijn ze van de visserij, hoe wordt er samengewerkt, hoe staat het met leeftijd en opvolgingssituatie, hoe belangrijk is de IJsselmeervisserij voor deze vissers? Hoe verweven is het bedrijf met de familie en familiegeschiedenis? Deze vraag is belangrijk om inzicht te krijgen in herstructureringsmogelijkheden. Dan is er ook de vraag hoe vissers zelf aankijken tegen de herstructurering en hoe zij in het licht van alle ontwikkelingen hun toekomst en die van hun bedrijf zien.

De derde vraag is of inzicht kan worden verkregen in de mogelijkheden om de visserijcapaciteit te verminderen via vrijwillige uitkoop en met welke kosten dit gepaard gaat. Hoe staan vissers hierin, welke ondernemers hebben hier belangstelling voor? Gecombineerd met de eerste vraag over de economische waarde kan dan inzicht worden verkregen in de kosten voor het vrijwillig uitkopen van visserij capaciteit.

Ten slotte is er de vraag of, wanneer vrijwillige uitkoop onvoldoende resultaat zou hebben, aanvullende verplichte maatregelen genomen moeten worden, zoals bijvoorbeeld een snoekbaarsquotum en/of een verbod op de zegenvisserij. Daarbij moet ook worden bepaald met welke kosten dit gepaard gaat.

\subsection{Doel}

Het project kent de volgende doelen:

- het actualiseren van de economische waarde van de IJsselmeervisserij en daaraan gekoppelde de opkoopwaarde van de verschillende vistuigen;

- het in beeld brengen van de sector en het toekomstperspectief dat vissers voor zichzelf zien in het licht van de ontwikkelingen van de voorbije jaren en in het bijzonder de herstructurering (vissers, visserijbedrijven, leeftijd ondernemers, opvolgingssituatie en toekomstperspectief);

- inzicht geven in vrijwillige uitkoopmogelijkheden en kosten ervan, de economische gevolgen van aanvullende (verplichte) maatregelen en het doen van aanbevelingen voor sociaal flankerende maatregelen.

De IJsselmeervisserij bestaat uit schubvisvisserij, aalvisserij en wolhandkrabvisserij. Specialisatie van visserij is mogelijk maar genoemde soorten zijn ook vaak bijvangst van de andere visserijen, en dus is er grote samenhang tussen de verschillende visserijen. In het actieplan wordt genoemd dat bij de herstructurering naast de schubvisvisserij, indien daar goede redenen voor zijn, ook de visserij op aal en schaaldieren (wolhandkrab) zal worden betrokken. Daarom wordt in deze studie de totale IJsselmeervisserij onderzocht, dus zowel de visserij op schubvis als op aal en wolhandkrab.

\subsection{Opbouw van het rapport}

Hoofdstuk 2 gaat over vissers, bedrijven, vangsten en opbrengsten. Hierin komt de structuur en economische waarde van de IJsselmeervisserij aan bod. Na een analyse van de verschillende gegevensbronnen worden de vangsten en opbrengsten bepaald voor de totale IJsselmeervisserij.

Hoofdstuk 3 gaat over de waarde van visrechten. In dit hoofdstuk worden ook de vangsten per vistuig en de vrije marktwaardes van de verschillende vistuigen beschreven.

Hoofdstuk 4 beschrijft de interesse in vrijwillige opkoopregelingen en de eventuele kosten van vrijwillige uitkoop. Ook worden de kosten van aanvullende maatregelen beschreven. Aan het eind van dit hoofdstuk wordt de behoefte aan flankerende maatregelen beschreven.

In hoofdstuk 5 worden een aantal discussiepunten benoemd bij de uitkomsten van het onderzoek. Hoofdstuk 6 sluit af met de meest belangrijke conclusies en de antwoorden op de onderzoeksvragen. 


\section{Vissers, bedrijven, vangsten en opbrengsten}

\section{$2.1 \quad$ Bronnen}

\subsubsection{Gegevensbestanden}

Voor de kwantitatieve analyse is gebruikgemaakt van een groot aantal databestanden die beschikbaar zijn gekomen via PO IJsselmeer, IJsselmeerafslag Urk en RVO. Deze bestanden bevatten vangsten, aanlandingen en/of besommingen van IJsselmeervis, maar hebben hun beperkingen als het gaat om de totale IJsselmeervisserij. Ook kennen de bestanden verschillende tijdsreeksen: gegevensbronnen zijn vanaf verschillende jaren opgestart of betrouwbaar. Afhankelijk van de gegevensbronnen kunnen hierdoor verschillende tijdreeksen in dit rapport worden weergegeven. Dit wordt hierna verder toegelicht. Het gaat om de volgende gegevens:

- Aanlanddata van de Producenten Organisatie (PO) IJsselmeer: jaarlijkse aanlandingen van de diverse vissoorten (inclusief wolhandkrab) van de leden van PO IJsselmeer, geleverd via afslag en buiten afslag om. PO-leden hebben de verplichting om alle aanlandingen aan de PO te melden. De PO verwerkt deze tot een jaaroverzicht. De gegevens betreffen alleen de PO-leden; niet-PO-leden vallen hier dus buiten. Tot en met 2015 was er één visser die geen lid was van de PO; daarna zijn er enkele leden geweest die hun lidmaatschap hebben opgezegd, maar die zich daarna ook weer hebben aangemeld. Sinds 2018 zijn weer bijna alle vissers lid. De PO-gegevens bevatten dus een bijna volledig overzicht van alle bedrijven, onder de veronderstelling dat alle aanlandingen door de leden zijn doorgegeven aan de PO. In januari 2021 heeft de PO de gegevens geactualiseerd, en met name op het onderdeel van brasemvangsten inclusief de pootvis. Deze geactualiseerde gegevens zijn in dit rapport opgenomen.

- Aanvoergegevens van de IJsselmeerafslag Urk en de afslagen in Den Oever en Volendam: deze gegevens betreffen de aangevoerde hoeveelheden en prijzen van de diverse vissoorten (inclusief wolhandkrab). Van de IJsselmeerafslag Urk is gedetailleerde informatie beschikbaar. De afslagen Den Oever en Volendam hebben informatie verstrekt over totale jaaraanvoer en prijzen.

- Visserij Registratie en Informatie Systeem (VIRIS) aal van Rijksdienst voor Ondernemend Nederland (RVO). Dit (logboek)bestand bevat de gegevens van aalvangsten van alle aalvissers, dus ook van de IJsselmeervissers. Aalvissers hebben vanuit de Europese aalverordening de verplichting de aalvangsten te registreren en door te geven aan RVO, die deze vangsten opneemt in het digitale VIRIS-bestand.

- Schubvislogboeken van de vissers. Dit is een registratiesysteem voor de IJsselmeervissers, waarin zij van schubvis de soorten en hoeveelheden aanlandingen en tijdstippen daarvan vastleggen voor staande netten, zegen en grote fuiken. Dit systeem is met ingang van 2015 ingevoerd en verplicht voor alle IJsselmeervissers. Wageningen Marine Research (WMR) voert in opdracht van RVO de controle op de registratie uit.

- Overzichten van uitgegeven vergunningen en bijbehorende merkjes naar vergunninghouder en gegevens van onderlinge huur en verhuur van RVO. Dit geeft mede inzicht in de omvang van de bedrijven en de variatie daarin.

- Informatie van vishandelaren over wolhandkrab. Uit een vorige studie bleek een groot verschil tussen de aanvoer op de markt en de PO-registratie. Voor wolhandkrab is een apart registratiesysteem niet verplicht. Ten behoeve van deze studie is bij enkele handelaren gevraagd naar de handel, omzet en herkomst van wolhandkrab. Deze informatie is in dit onderzoek meegenomen ter aanvulling op de PO-gegevens.

\subsubsection{Gesprekken met vissers en andere betrokkenen}

Voor het inzicht in de bedrijfsstructuur, samenwerkingsverbanden, demografische kenmerken en opvolgingssituatie zijn persoonlijke gesprekken gevoerd met IJsselmeervissers. In totaal zijn 37 gesprekken met vissers gevoerd waarvan 9 gesprekken telefonisch hebben plaatsgevonden. De vissers vertegenwoordigden allemaal een visserijbedrijf. De gesprekken vonden plaats in de periode 
april tot en met augustus. De Kamerbrief (6 oktober 2020) was toen nog niet verstuurd maar er was al wel kennis over de mogelijke maatregelen. Deze kennis veroorzaakte veel onrust die goed merkbaar was tijdens de gesprekken. Twee IJsselmeervissers zagen het nut van een gesprek niet in en hebben afgezien van deelname. De ontbrekende informatie van deze vissers is voor zover mogelijk via andere kanalen beschikbaar gekomen.

Ter voorbereiding op deze gesprekken is aan alle vissers via de PO IJsselmeer een brief verstuurd met de aankondiging dat ze benaderd zouden worden door onderzoekers van Wageningen Economic Research voor een gesprek. De gesprekken zijn gevoerd aan de hand van een gestandaardiseerde vragenlijst. De resultaten van de gesprekken die bijdragen aan inzicht over mogelijkheden voor herstructurering staan in dit hoofdstuk.

Daarnaast zijn ook gesprekken gevoerd met de betrokken partijen bij het Actieplan toekomstig visserijbeheer IJsselmeer en een vertegenwoordiger van de gemeente Urk, omdat deze vertegenwoordiger zitting heeft in de werkgroep die het herstructureringsplan uitwerkt. Deze gesprekken waren nodig om de ontwikkelingen op het IJsselmeer beter te kunnen duiden en om inzicht te krijgen in de rollen en belangen van deze betrokkenen. De gesprekken met deze betrokkenen zijn voorafgaand aan de gesprekken met de vissers gevoerd.

\subsection{Aanlandingen}

Voor de vaststelling van de economische waarde van de IJsselmeervisserij zijn de diverse beschikbare gegevensbronnen gebruikt en gecombineerd.

De IJsselmeerafslag Urk heeft aanvoergegevens, maar dit betreft eveneens de leveringen van nietIJsselmeervissers. De leveringen van niet-IJsselmeervissers zijn eruit gefilterd. Daarnaast wordt niet alle IJsselmeervis via de IJsselmeerafslag verkocht, dus is er met deze afslaggegevens geen compleet beeld te schetsen. De PO-leden hebben een registratieplicht via de afslag maar het is toegestaan om, na goedkeuring van de PO, ook buiten de afslag om te leveren. Door de PO-gegevens te combineren met de afslaggegevens is berekend dat over het algemeen circa $90 \%$ van alle IJsselmeervis via de IJsselmeerafslag wordt verhandeld en/of geregistreerd. Dit percentage verschilt echter tussen vissoorten. Wolhandkrab en pootvis (vooral brasem) worden van oudsher meer buiten de afslag om verhandeld dan de andere schubvissoorten. Bij paling is er de laatste jaren een trend te zien dat ook meer buiten de afslag om wordt verhandeld.

De volgende figuren geven inzicht in de seizoensmatige en recente aanvoer van IJsselmeervis bij de IJsselmeerafslag Urk. Figuur 2.1 geeft een overzicht van de maandelijkse aanvoer van de belangrijkste soorten voor de periode van januari 2018 tot en met december 2020. Voor snoekbaars en blankvoorn zien we in 2019 hogere vangsten dan in 2018; voor baars en brasem zien we in 2019 iets lagere vangsten. Voor snoekbaars zien we in augustus en september 2020 lagere aanlandingscijfers dan het jaar daarvoor, terwijl de vangsten in de maanden erna bijna vergelijkbaar zijn met 2019. Voor aal en wolhandkrab zien we in 2020 een gelijke trend vergeleken met 2019. Bij de IJsselmeerafslag wordt de meeste IJsselmeervis aangevoerd en verondersteld kan worden dat de gegevens van deze afslag een goed inzicht in het verloop van vangsten geven. 

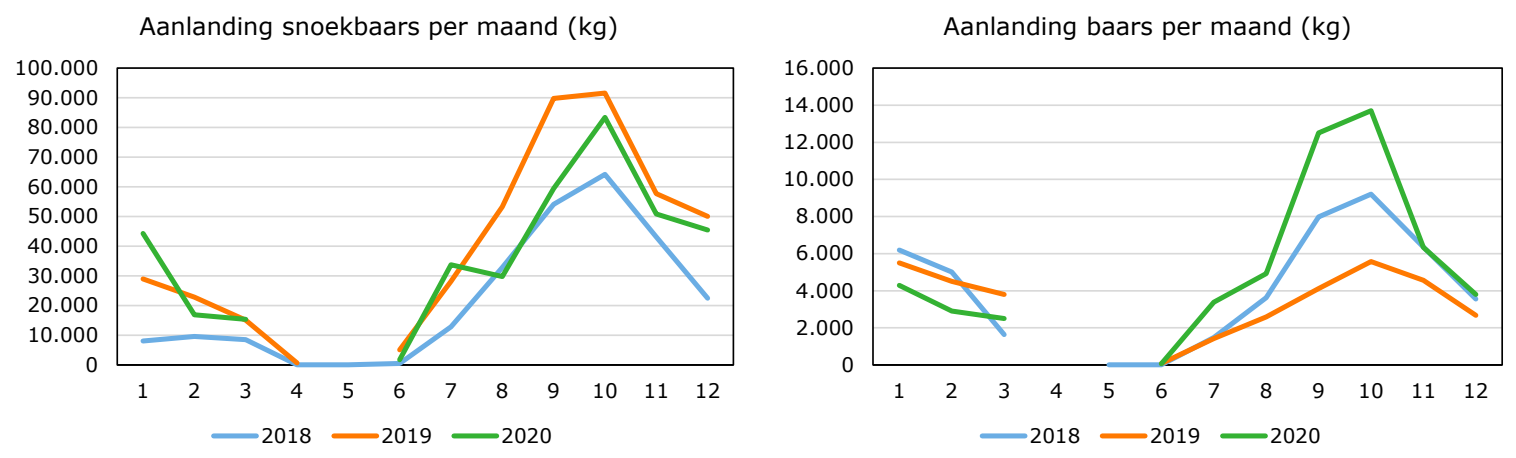

Aanlanding blankvoorn per maand $(\mathrm{kg})$

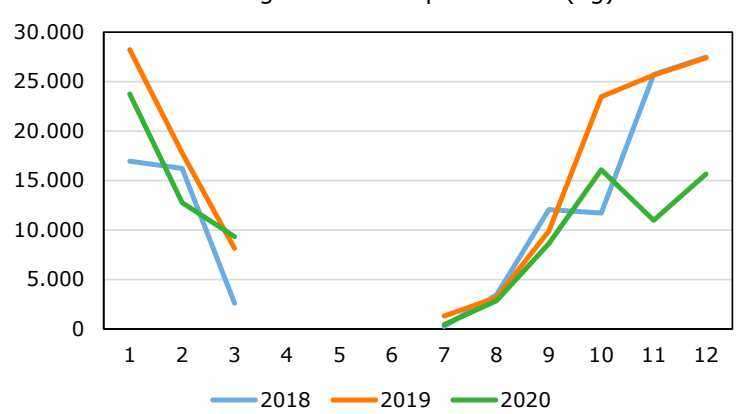

Aanlandingen brasem per maand $(\mathrm{kg})$

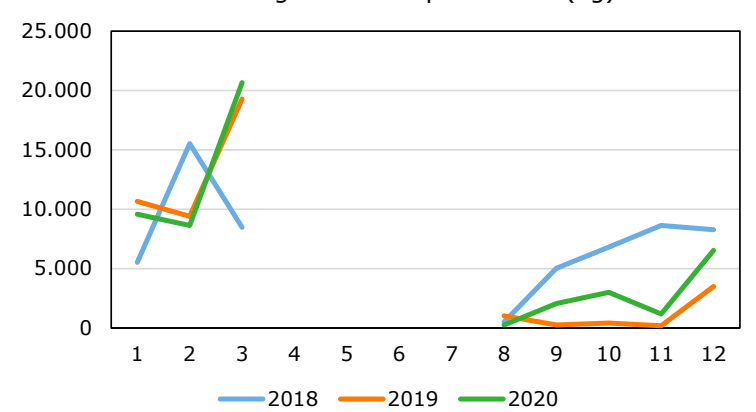

Aanlandingen aal per maand $(\mathrm{kg})$
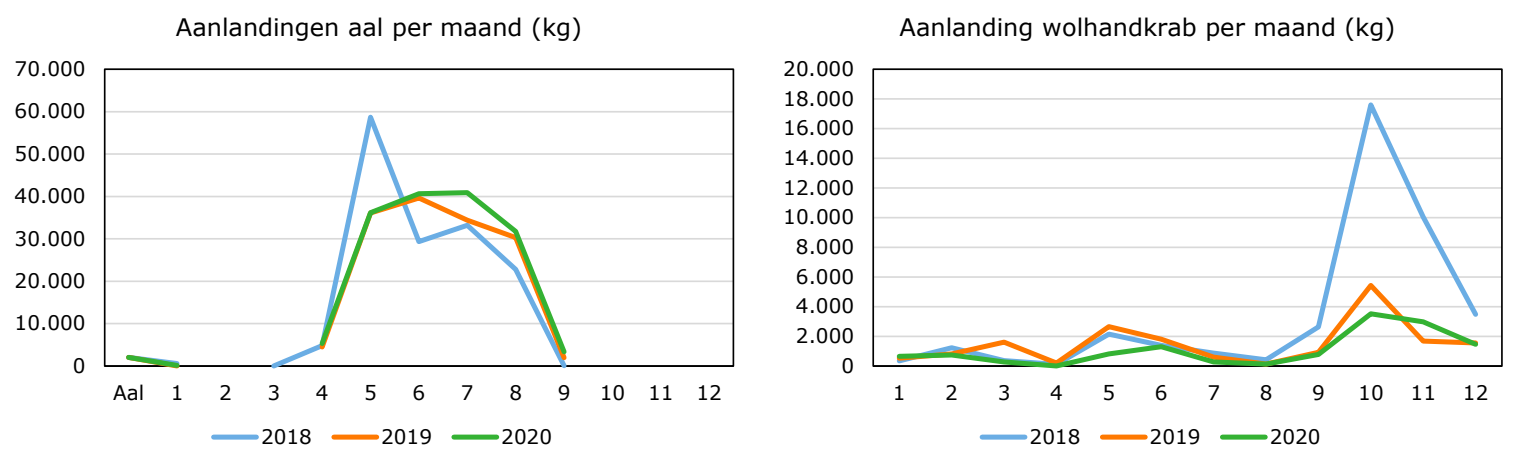

Figuur 2.1 Maandelijkse aanvoer van verschillende IJsselmeervissoorten bij IJsselmeerafslag Urk

Spiering wordt de laatste jaren niet meer aangevoerd. De laatste spieringvisserij in het IJsselmeer heeft in het voorjaar van 2012 plaatsgevonden.

PO IJsselmeer heeft langjarige informatie over de aanlandingen van IJsselmeervis beschikbaar.

Figuur 2.2 geeft een overzicht van de aanlandingen van de meest belangrijke vissoorten van de POleden vanaf het jaar 2000. 


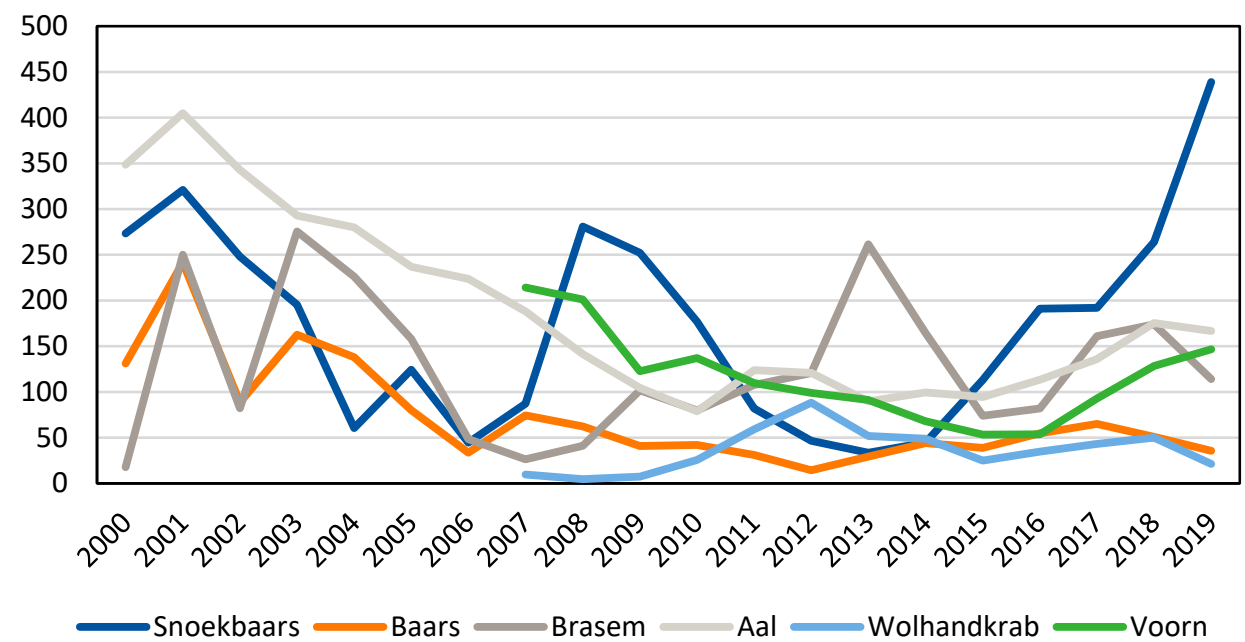

Figuur 2.2 Aanlanding van IJsselmeervis x $1.000 \mathrm{~kg}$ vanaf 2000 tot en met 2019 Bron: PO IJsselmeer.

Er zijn ook gegevens uit andere bronnen beschikbaar, zoals de schubvislogboeken en de aalregistratie (VIRIS), doch die zijn voor een minder lange periode beschikbaar. Deze gegevens zijn gebaseerd op de registratie van visserijondernemers zelf. Uit een vergelijking van deze verschillende bestanden blijkt dat er soms grote verschillen zijn tussen de registratiehoeveelheden en de afslag- en POgegevens. De oorzaken hiervan zijn niet altijd duidelijk, en zijn niet nader onderzocht. Echter, door combinatie van deze diverse gegevensbronnen is getracht een zo volledig mogelijk beeld te schetsen van de vangsten en de economische waarde ervan.

Voor de economische waardebepaling zijn door combinatie van de verschillende informatiebronnen de aanlandingen en de besommingen per (geanonimiseerd) bedrijf berekend over de jaren 2018 en 2019. ${ }^{1}$ Hierbij is de hoogst geregistreerde vangst bepalend geweest voor de vaststelling van de jaaraanlandingen. Met andere woorden: wordt bij de logboeken van schubvis of van aal een andere waarde vermeld dan bij de PO-registratie of de afslag, dan wordt de hoogste waarde als waar aangenomen, onder de veronderstelling dat het verschil buiten de afslag om is afgezet. De op deze manier berekende totale aanlanding van vis (hierna de berekening van Wageningen Economic Research genoemd), komt door deze methodiek hoger uit dan de PO-registratie. Deze methode is ook in een vorige studie toegepast (Zaalmink et al., 2017). Tabel 2.1 geeft het overzicht van de aldus berekende aanlandingen per vissoort voor de jaren 2018 en 2019 . Hierbij wordt ook een categorie overige vissoorten onderscheiden, waaronder vooral blei, snoek en bot.

${ }^{1}$ Van het jaar 2017 zijn geen individuele afslaggegevens beschikbaar, waardoor deze berekening voor 2017 niet kon worden uitgevoerd. 
Tabel 2.1 Aanlandingen per vissoort (x $1.000 \mathrm{~kg}$ ) per jaar (2018 en 2019) naar informatiebron en berekeningsmethodiek

\begin{tabular}{|c|c|c|c|c|}
\hline 2018 & PO & Afslag Urk & SRS & Berekening \\
\hline \multirow[t]{2}{*}{ Vissoort } & & & Schubvis/ VIRIS & Wageningen \\
\hline & & & (aal) & Economic Research \\
\hline Snoekbaars & 263,9 & 258,7 & 304,4 & 312,2 \\
\hline Brasem & 173,8 & 60,0 & 180,4 & 182,8 \\
\hline Baars & 50,9 & 45,1 & 52,7 & 54,8 \\
\hline Voorn & 128,3 & 117,6 & 132,1 & 142,2 \\
\hline Spiering & 0 & 0 & - & - \\
\hline Krab & 50,1 & 41,8 & - & 66,8 \\
\hline Aal & 175,4 & 160,9 & 281,1 & 294,8 \\
\hline Overig & 24,2 & 14,9 & - & 21,0 a) \\
\hline
\end{tabular}

a) Hoeveelheid is lager dan PO-opgave doordat pootvis hier is opgenomen onder post brasem in tegenstelling tot PO-opgave.

Bronnen: PO, Afslag Urk, afslag Den Oever, RVO, Wageningen Marine Research; bewerking Wageningen Economic Research.

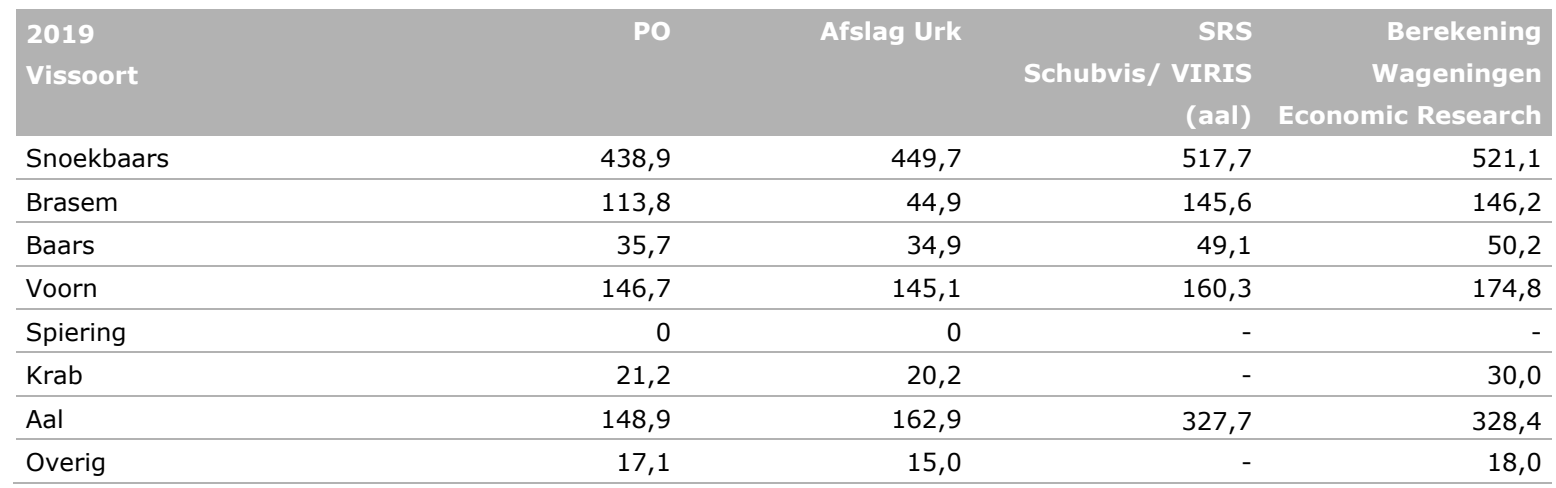

Bronnen: PO, Afslag Urk, afslag Den Oever, RVO, Wageningen Marine Research; bewerking Wageningen Economic Research.

De aanlandingen zoals op deze wijze berekend zijn dus hoger dan uit de gegevens van afslag en PO IJsselmeer blijkt. De eigen registratiesystemen (logboeken) van de IJsselmeervissers laten over het algemeen hogere vangsten zien, met name voor snoekbaars, brasem en aal. Dit zijn ook soorten die deels buiten de afslag om worden afgezet. Ter illustratie: figuur 2.3 geeft de verschillen weer tussen de PO-opgaven en de registratie door vissers voor aal en figuur 2.4 voor de verschillende schubvissoorten. Voor brasem kan het verschil worden verklaard door de vangst van pootvis met de zegen. Deze pootvis wordt buiten de afslag om verhandeld, en is ook niet opgenomen in de POregistratie.

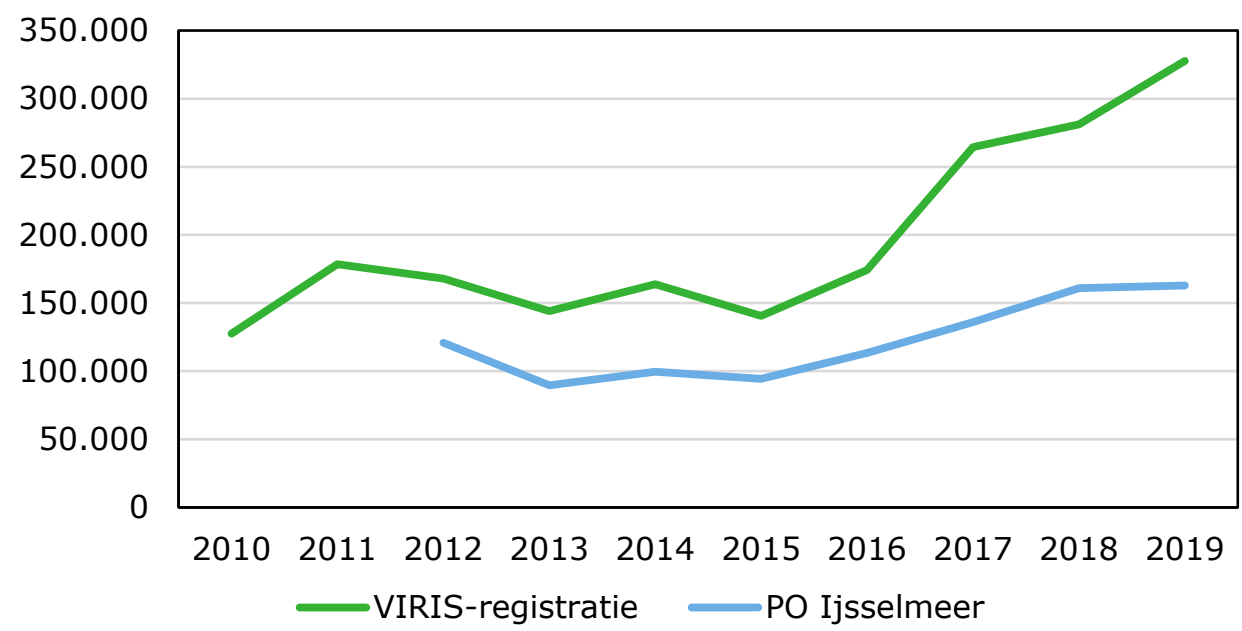

Figuur 2.3 Aanlanding van aal uit het IJsselmeer volgens VIRIS-registratie en PO IJsselmeer 
Aanlandingen schubvis

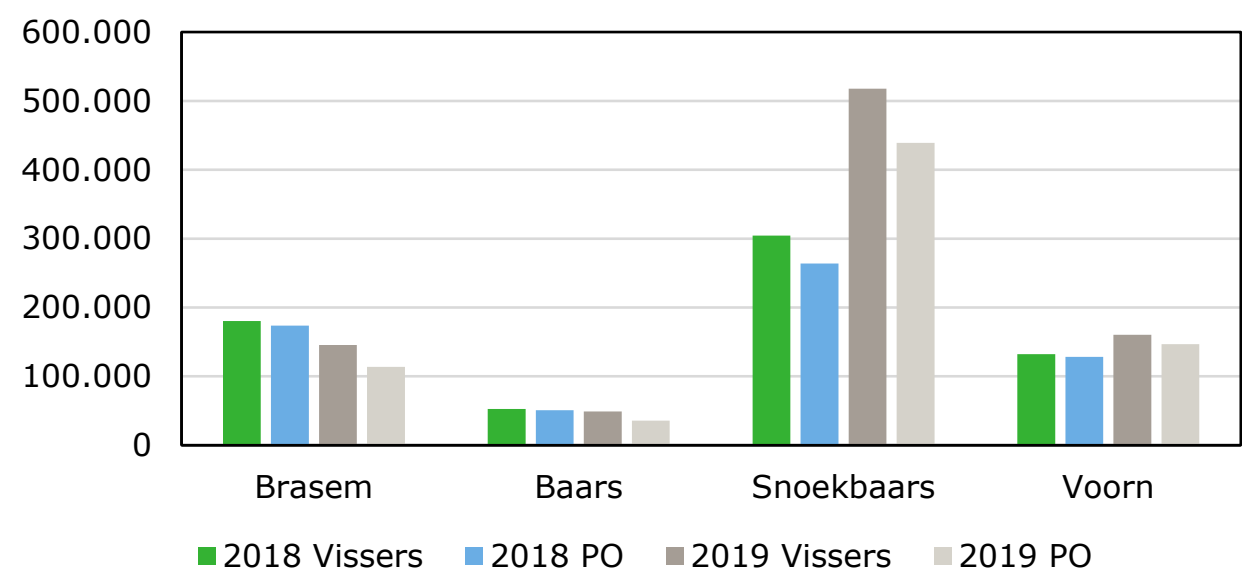

Figuur 2.4 Aanlanding van schubvis uit het IJsselmeer volgens schubvisregistratie (vissers) en PO IJsselmeer

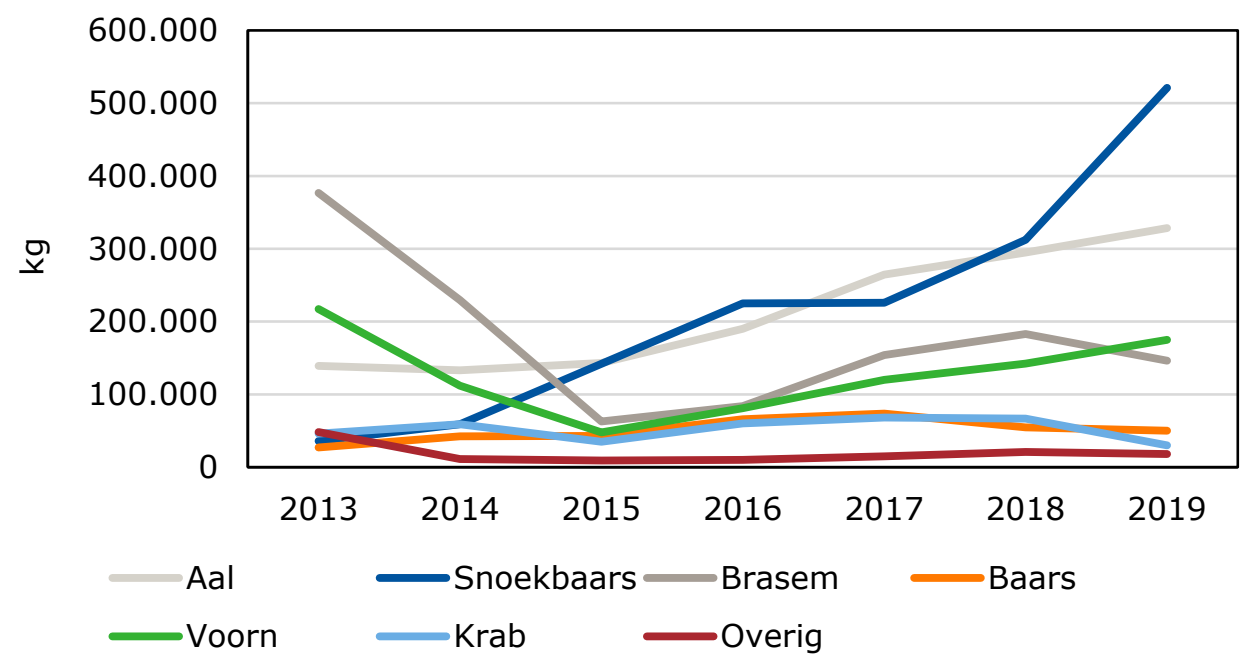

Figuur 2.5 Totale aanlandingen van vis uit het IJsselmeer volgens de berekening van Wageningen Economic Research

De totale aanlandingen van alle vissoorten wordt in figuur 2.5 weergegeven. Zie hiervoor ook tabel 2.2.

Tabel 2.2 Aanlandingen van alle vissoorten van het IJsselmeer volgens berekening Wageningen Economic Research $(x 1.000 \mathrm{~kg})$

\begin{tabular}{lrrrrrrr} 
& 2013 & 2014 & 2015 & 2016 a) & 2017 & 2018 & 2019 \\
Aal & 139,1 & 133,1 & 143,1 & 190,0 & 264,5 & 294,8 & 328,4 \\
\hline Snoekbaars & 36,0 & 59,0 & 142,1 & 225,0 & 226,0 & 312,2 & 521,1 \\
\hline Brasem & 376,7 & 229,7 & 62,8 & 84,0 & 154,2 & 182,8 & 146,2 \\
\hline Baars & 27,1 & 42,3 & 42,9 & 66,0 & 73,6 & 54,8 & 50,2 \\
\hline Voorn & 217,2 & 111,9 & 47,8 & 81,0 & 119,8 & 142,2 & 174,8 \\
\hline Krab & 46,0 & 59,0 & 35,0 & 60,0 & 68,2 & 66,8 & 30,0 \\
\hline Overig & 48,2 & 11,2 & 9,2 & 10,0 & 15,0 & 21,0 & 18,0 \\
\hline
\end{tabular}

a) tot en met 2016 afgeleid van Zaalmink et al. (2017). 


\subsection{Prijzen en besommingen}

Tabel 2.3 geeft de kg prijzen weer voor de verschillende vissoorten. De gegevens zijn afkomstig van de IJsselmeerafslag Urk. Voor aal zien we vanaf 2018 een sterke terugval in de prijs als gevolg van gestegen importen, dit geldt in mindere mate ook voor snoekbaars. De duurste 'vis' is wolhandkrab, gevolgd door aal en snoekbaars. Opgemerkt moet worden dat het om de prijs van 'dode' vis gaat. Pootvis wordt buiten de afslag om geleverd, en de prijzen daarvan zullen verschillen ten opzichte van die vis die via de afslag wordt geleverd. De meeste pootvis bestaat uit brasem en die wordt met de zegen gevangen. Uit gegevens van PO IJsselmeer blijkt dat brasem als pootvis gemiddeld 0,90 euro per kg meer opbrengt dan dode brasem.

Tabel 2.3 Afslagprijzen per vissoort in euro/kg

\begin{tabular}{lrrrrrrr} 
Jaar & 2013 & 2014 & 2015 & 2016 & 2017 & 2018 & 2019 \\
Aal & 11,62 & 10,15 & 10,96 & 11,80 & 11,50 & 7,32 & 7,62 \\
\hline Snoekbaars & 7,87 & 6,68 & 6,22 & 5,92 & 7,01 & 5,64 & 5,17 \\
\hline Brasem & 0,73 & 0,91 & 0,78 & 0,71 & 0,71 & 0,60 & 0,60 \\
\hline Baars & 1,55 & 1,37 & 1,82 & 2,08 & 1,92 & 2,00 & 2,40 \\
\hline Voorn & 1,16 & 1,09 & 1,13 & 1,16 & 1,16 & 1,07 & 1,14 \\
\hline Krab & 14,96 & 13,23 & 18,18 & 16,58 & 17,00 & 13,91 & 16,68 \\
\hline Overig & 1,14 & 1,25 & 2,18 & 2,19 & 2,73 & 2,67 & 2,15 \\
\hline
\end{tabular}

De besommingen of de opbrengsten uit de IJsselmeervisserij bestaan uit de hoeveelheden gevangen vis vermenigvuldigd met de prijs. Bij de berekening wordt ervan uitgegaan dat de vis die niet via de afslag is geleverd dezelfde prijs op zou brengen als via de afslag. Voor brasem is hiervoor een uitzondering gemaakt. Een derde van de brasemvangsten wordt via de afslag geleverd (zie paragraaf 2.5) en twee derde bestaat uit pootvis, die gemiddeld 0,90 euro per kg meer opbrengt (bron: PO IJsselmeer). Hiervoor zijn de totale opbrengsten van brasem gecorrigeerd. Figuur 2.6 geeft een overzicht van de opbouw van de besomming vanaf het jaar 2013.

\section{Besomming IJsselmeer WEcR benadering}

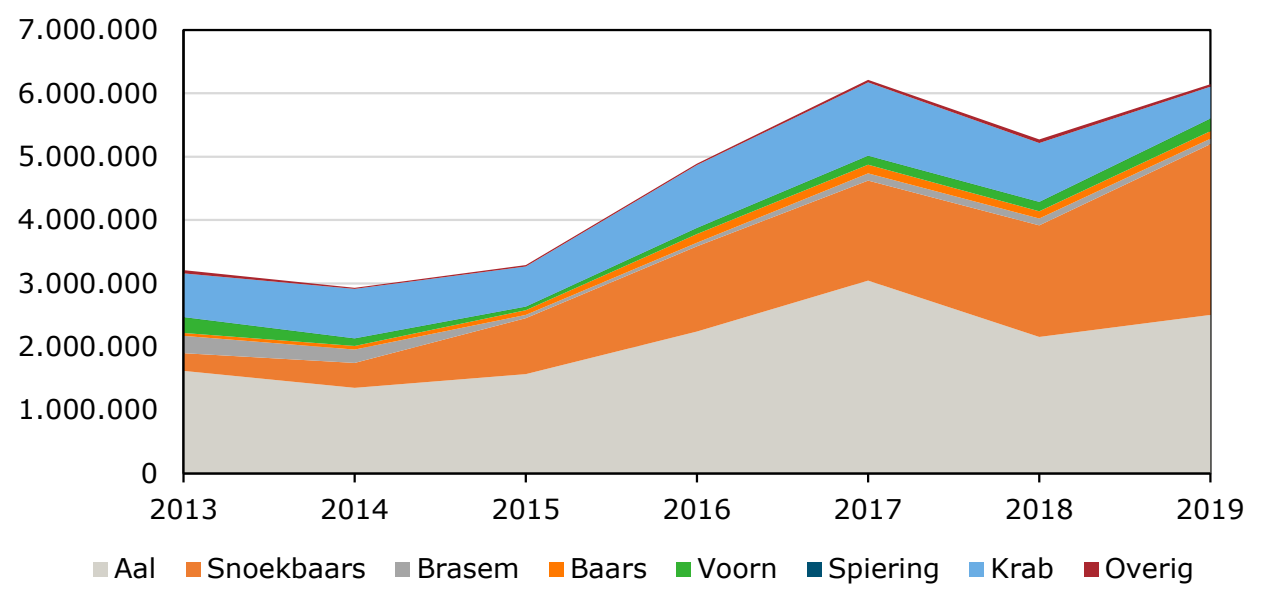

Figuur 2.6 Totale opbrengsten (in euro) uit vis uit het IJsselmeer volgens berekening Wageningen Economic Research

Tabel 2.4 geeft dezelfde informatie getalsmatig. Hieruit is af te leiden dat de totale opbrengst van het IJsselmeer is toegenomen van 2,9 mln. euro in 2014 tot 6,2 mln. euro in 2019. Het meest belangrijk zijn snoekbaars (44\%) en aal (41\%). Samen vormen zij bijna $85 \%$ van de totale opbrengsten. 
Tabel 2.4 Opbrengsten per vissoort en totaal (x 1.000 euro)

\begin{tabular}{|c|c|c|c|c|c|c|c|}
\hline & 2013 & 2014 & 2015 & 2016 & 2017 & 2018 & 2019 \\
\hline Aal & 1.616 & 1.351 & 1.568 & 2.241 & 3.042 & 2.157 & 2.503 \\
\hline Snoekbaars & 283 & 394 & 884 & 1.343 & 1.584 & 1.761 & 2.694 \\
\hline Baars & 42 & 58 & 78 & 138 & 141 & 110 & 120 \\
\hline Voorn & 252 & 122 & 54 & 94 & 139 & 152 & 199 \\
\hline Overig & 55 & 14 & 20 & 22 & 41 & 56 & 39 \\
\hline Totaal & 3.211 & 2.929 & 3.380 & 4.932 & 6.308 & 5.383 & 6.231 \\
\hline
\end{tabular}

\subsection{Bedrijven en vergunningen}

De overheid reguleert de beroepsmatige visserij op het IJsselmeer via het verlenen van vergunningen aan vergunninghouders: dit zijn natuurlijke rechtspersonen. Deze vergunninghouders moeten in het bezit zijn van een geregistreerd schip, maar dit hoeft niet een actief schip te zijn. Er zijn vergunninghouders die meerdere vergunningen hebben maar slechts één geregistreerd schip. Dit is toegestaan.

Deze vergunninghouders kunnen individueel vissen, maar ook in samenwerking met andere vissers of ze kunnen hun visrechten verhuren. Het kan ook zijn dat ze én niet verhuren én niet vissen, en dat de vergunning dus ongebruikt blijft.

Voor deze studie maken we onderscheid in vissers en bedrijven. Een visser (ondernemer) is iemand die volwaardig meewerkt, en/of mede-eigenaar is van het bedrijf. Een bedrijf is gedefinieerd als een eenmansbedrijf, een meermansbedrijf of als een eenheid waarbij vissers nauw samenwerken via gezamenlijk gebruik van schip en vistuigen. Familiebedrijven, maatschappen of andere samenwerkingsverbanden zijn in deze studie dus gedefinieerd als één bedrijf, ook als dit fiscaal/juridisch niet het geval zou zijn. Een bedrijf bestaat in die gevallen dus uit meerdere vissers. De resultaten van de studie worden afhankelijk van de interpretatie uitgedrukt per bedrijf en soms per visser. Tabel 2.5 geeft een overzicht van de aantallen vergunningen, bedrijven, schepen en ondernemers actief in de IJsselmeervisserij in 2020. In het kader van dit onderzoek is met alle bedrijfsvertegenwoordigers (op 2 na) gesproken (zie paragraaf 2.1.2) Gegevens in tabel 2.5 zijn afkomstig uit deze interviews en RVO-informatie over vergunningen en certificaten.

Tabel 2.5 IJsselmeervisserij 2020: aantal vergunninghouders, bedrijven en vissers

\begin{tabular}{lc} 
Vergunninghouders & Aantal \\
\hline Aantal vergunningen belegd bij vissers & 77 \\
\hline Aantal vergunningen in bezit bij PO & 2 \\
\hline Aantal bedrijven met vergunning & 39 \\
\hline Actieve visserijbedrijven & 31 \\
\hline w.V. aantal bedrijven met minimaal 25\% visrechten in Randmeren en overige wateren & 5 \\
\hline w.v. aantal bedrijven met hoofdinkomen uit de IJsselmeervisserij & 25 \\
\hline Gespecialiseerde schubvisbedrijven & 10 \\
\hline Gespecialiseerde aalbedrijven & 9 \\
\hline Gemengde bedrijven & 12 \\
\hline Aantal bedrijven met zegenvergunningen in eigendom & 11 \\
\hline Aantal bedrijven met zegenvergunningen na huur/verhuur & 6 \\
\hline Actieve vissers & 63 \\
\hline
\end{tabular}

Bronnen: RVO, Wageningen Economic Research. 
We constateren dat de databronnen in de manier van registreren niet dezelfde begrippen hanteren en dus niet eenduidig en daarmee niet vergelijkbaar zijn. Visserijondernemers, schepen en bedrijven worden door elkaar gebruikt. Het blijkt dus dat:

- visserijondernemers soms meer dan één schip hebben

- visserijondernemers soms samen eigenaar zijn van één of meer schepen (vaak familiebedrijven of maatschappen)

- visserijondernemers van fiscaal verschillende bedrijven ook nauw samenwerken, samen op de afslag leveren en/of samen opgave doen in bijvoorbeeld het SRS (Schubvis Registratie Systeem).

De aantallen die in tabel 2.5 worden genoemd zijn niet allemaal optelbaar, er kunnen dubbeltellingen voorkomen. Er zijn acht bedrijven met een vergunning die niet of nauwelijks actief zijn op het IJsselmeer. Er zijn 31 actieve visserijbedrijven die regelmatig vissen en een belangrijk deel van hun inkomen behalen uit de visserij. Van deze 31 bedrijven zijn er 25 die volledig afhankelijk zijn van de visserij; de overige 6 hebben naast de visserij ook nog een andere inkomstenbron, maar hebben de visserij aanvullend nodig voor een volledig inkomen. Van de 31 bedrijven zijn er 10 die vooral schubvisrechten hebben (met soms enkele aalvistuigrechten), 9 bedrijven die vooral aalvistuigrechten hebben en 12 bedrijven zijn van beide visserijen afhankelijk. Op de 31 bedrijven werken 63 ondernemers (vissers), wat neerkomt op 2,0 ondernemer per bedrijf.

\subsection{Besomming per visser en bedrijfstype}

De financiële opbrengst van vis wordt in de visserij de besomming genoemd. Naast besomming kunnen er andere opbrengsten zijn uit activiteiten zoals monitoringsonderzoek of ander werk voor derden. De besomming is niet gelijk aan het inkomen, daarvoor moeten de (bedrijfs)kosten nog in mindering worden gebracht. Figuur 2.7 geeft inzicht in de spreiding van de besomming (opbrengsten uit IJsselmeervis) per visser/ondernemer, waarbij de vangstregistratie, de leveringen aan de IJsselmeerafslag en de PO-gegevens van 2019, en de prijsgegevens van de afslag als uitgangspunt zijn genomen. De 63 actieve vissers hebben een gemiddelde besomming van bijna 87.500 euro per visser. Net zoals in andere sectoren zoals bijvoorbeeld de landbouw is de spreiding rondom dit gemiddelde groot: 14 vissers behalen een besomming van minder dan 25.000 euro, terwijl 15 andere vissers meer dan 125.000 euro besommen. Deze spreiding kan door het verschil in bedrijfsgrootte worden veroorzaakt maar ook door het gedrag en vakbekwaamheid van de visser: worden de vistuigen intensief gebruikt of niet en waar worden ze ingezet? Zoals eerder vermeld zijn er vissers die een aanvullend inkomen hebben uit een andere baan of AOW/pensioen, en dus economisch niet (volledig) afhankelijk zijn van de visserij.

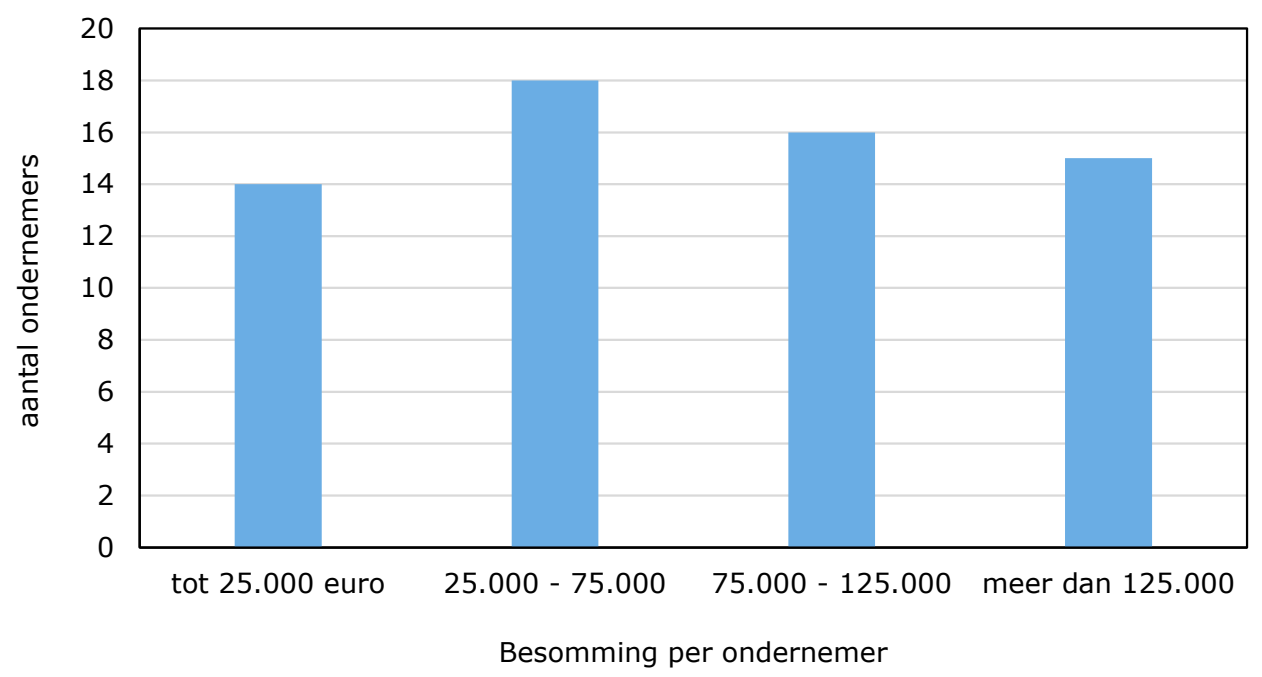

Figuur 2.7 Verdeling van de besomming per ondernemer in 2019 
In tabel 2.6 wordt de gemiddelde besomming per visser weergegeven voor de verschillende bedrijfstypen. De schubvisbedrijven besommen per visser het meest, gevolgd door de gemengde bedrijven en de aalbedrijven. Dit verschil is niet significant (berekend met behulp van een t-toets) door de grote spreiding tussen de vissers. De gemengde bedrijven zijn gemiddeld het grootst met 2,3 ondernemers per bedrijf. Door het ontbreken van de benodigde informatie kan dit niet voor voorgaande jaren worden berekend.

Tabel 2.6 Gemiddelde besomming en gemiddeld aantal vissers per bedrijfstype in 2019

\begin{tabular}{lllll} 
Specialisatie & Aantal bedrijven & $\begin{array}{l}\text { Besomming per bedrijf } \\
\text { (in euro) }\end{array}$ & $\begin{array}{l}\text { Gem, aantal vissers } \\
\text { per bedrijf }\end{array}$ & $\begin{array}{l}\text { Besomming per } \\
\text { visser (euro) }\end{array}$ \\
Aal & 9 & 161.000 & 1,89 & 85.200 \\
\hline Gemengd & 12 & 237.800 & 2,25 & 105.700 \\
\hline Schubvis & 10 & 197.800 & 1,80 & 109.900 \\
\hline
\end{tabular}

\subsection{Nadere typering van bedrijven en vissers}

In tabel 2.5 is een overzicht gegeven van aantal vergunningen, aantal bedrijven en de specialisatiegraad. Tabel 2.7 geeft een nader overzicht van de aard van de bedrijven met informatie die vooral uit de interviews is verkregen. De 39 bedrijven met vergunning kunnen als volgt worden ingedeeld.

Tabel 2.7 Aantal IJsselmeer visserijbedrijven met specifieke kenmerken

\begin{tabular}{lr} 
Kenmerk & 6 \\
\hline Bedrijven waarbij vergunning niet of nauwelijks wordt gebruikt & Aantal \\
\hline Bedrijven waarbij vergunning wel nodig is voor uitoefening beroep maar niet voor commerciële visserij & 15 \\
\hline Kleinschalige bedrijven (1-3 vissers) volledig afhankelijk van visserij & 10 \\
\hline Kleinschalige bedrijven (1-3 vissers) die visserij (willen) combineren met andere werkzaamheden & 4 \\
\hline Kleinschalige bedrijven die verder in de keten georganiseerd zijn & 2 \\
\hline Grotere bedrijven ( $>3$ vissers)
\end{tabular}

Totaal aantal bedrijven met vergunningen

Er zijn dus 6 bedrijven waarin geen of nauwelijks visserijactiviteit wordt ondernomen. Deze vissers zijn qua inkomen niet direct afhankelijk van de visserij, meestal vanwege de leeftijd (pensioen) of omdat er een ander hoofdberoep is. Een enkeling verhuurt de rechten maar het merendeel houdt de rechten in eigen beheer. Er zijn 2 bedrijven die de vergunning nodig hebben voor een ander beroep zoals bijvoorbeeld monitoring van visbestanden, en waarbij de vergunning noodzakelijk is om de werkzaamheden op het IJsselmeer te kunnen uitvoeren. Er resteren dan 31 visserijbedrijven met in totaal 63 actieve ondernemers die direct afhankelijk zijn van het inkomen uit de visserij. Verdere kenmerken van de bedrijven met vergunning zijn:

- 15 vissers hebben een kleinschalig bedrijf (één tot drie werknemers/vissers), en hebben zich volledig toegelegd op de IJsselmeervisserij, en zijn wat inkomen betreft afhankelijk van de visserij. Als er anderen meewerken, dan zijn dit directe familieleden, zoals broers of zonen. De mogelijkheid of de wil om andere werkzaamheden dan het vissen zelf op te pakken is er niet bij deze vissers. De vissers zijn graag op zichzelf en vinden het vissen op het IJsselmeer het mooiste werk dat er is. Als er in het verleden ander werk is gedaan, dan was dit een keuze uit armoede (bij slechte visserijinkomsten werd tijdelijk een baan aan de wal gezocht). Deze vissers geven aan dat ze niet geld gedreven zijn, maar dat het vissen voor hen een levenswijze is. Veelal is de IJsselmeervergunning al generaties lang in de familie en voelen ze zelf een bepaalde gedrevenheid en beoordelen hun potentiële opvolger, als hij ook wil vissen, ook op deze gedrevenheid. Deze vissers hebben geen strategie om het bedrijf veel verder te ontwikkelen. In het verleden zijn vooral noodzakelijke 
investeringen gedaan. Daar waar een visser een recht huurt is er meestal wel een wens om dit recht zelf te kopen, zodat er meer zekerheid en onafhankelijkheid is.

- 10 vissers hebben een kleinschalig bedrijf, waarbij er ook andere werkzaamheden dan vissen op het IJsselmeer worden uitgevoerd of waarbij de visser aangeeft dat hij dat graag zou willen. Het betreft vissers die breder inzetbaar willen en kunnen zijn en water gerelateerd werk hebben opgepakt. Dit werk ligt in bijna alle gevallen in het verlengde van de visserij. Voorbeelden zijn het maaien van waterplanten of het doen van (monitorings)onderzoek. Ook zijn er vissers die op ad-hocbasis hebben meegewerkt aan educatieprojecten. De basis ligt bij het visserijbedrijf, omdat de andere werkzaamheden niet structureel of van grote omvang zijn.

- 4 vissers hebben een bedrijf dat verder in de keten georganiseerd is. Denk hierbij aan de combinatie met een handelsbedrijf of het hebben van een winkel of viskramen. Deze ondernemers zijn voor hun inkomen veel minder afhankelijk van hun IJsselmeervergunning, maar zijn wel gehecht aan de IJsselmeervisserij. Ook hier zijn de vergunningen al generaties lang in de familie en denkt men niet aan verkopen en stoppen. De spanning en onzekerheid elk jaar rondom de regelgeving op het IJsselmeer wordt ook in deze groep gevoeld. Deze ondernemers hebben wel een bedrijf dat breder georganiseerd is, maar op 1 bedrijf na zijn het ook kleinschalige familiebedrijven.

- 2 vissers hebben een relatief groot bedrijf, waarbij er minimaal 4 tot 6 gezinnen van het bedrijf leven. $\mathrm{Zij}$ hebben de laatste jaren geïnvesteerd in de uitbreiding van het bedrijf. Er is bedrijfsopvolging en er moet bedrijfsmatig worden gewerkt, ook omdat er afgelost moet worden op het geld dat geleend is voor de investeringen. Deze bedrijven zijn ook typische familiebedrijven waarbij de vissers emotioneel aan het bedrijf en de visserij zijn verbonden. De visserij zit in de traditie van de familie. Deze bedrijven staan open voor verbreding van activiteiten, zoals het meedoen aan onderzoek.

De leeftijdsopbouw en opvolgingssituatie van de bedrijven staat in tabel 2.8 vermeld.

Tabel 2.8 Leeftijdsopbouw en opvolgingssituatie van bedrijfshoofden van de IJsselmeervisserij bedrijven

\begin{tabular}{lr} 
Categorie & Aantal bedrijven \\
$=<40$ jaar & 4 \\
\hline $41-=<50$ jaar & 8 \\
\hline$>50$ jaar, met opvolger & 11 \\
\hline$>50$ jaar, zonder opvolger & 11 \\
\hline$>50$ jaar, misschien opvolger & 3 \\
\hline Onbekend & 2 \\
\hline Totaal & 39 \\
\hline
\end{tabular}

Er zijn 12 bedrijven met een bedrijfshoofd jonger dan 50 jaar, voor deze bedrijven is de bedrijfsopvolging nog minder van belang. Van de 27 bedrijfshoofden die ouder zijn dan 50 jaar hebben er 11 zeker een opvolger, 3 misschien en 2 zijn onbekend. Van 11 bedrijven is bekend dat er geen opvolger aanwezig is. Zeven bedrijven die mogelijk van een uitkoop gebruik willen maken (zie 3.3) hebben ook geen opvolger. De 2 grote bedrijven hebben zeker een opvolger. Er zijn zeker dus 23 bedrijven (12 jonger dan 50 jaar en 11 met opvolger) die de komende 15 jaar of langer normaal gesproken zullen continueren. Van het totaal aantal bedrijven gaat het globaal dus om 1/3 jongere ondernemers, 1/3 met opvolger en 1/3 zonder opvolger. Als we dit vergelijken met opvolgingssituatie in de landbouw: in 2016 is 36\% van de bedrijfshoofden jonger dan 50 jaar, heeft $25 \%$ een opvolger en $39 \%$ geen opvolger (bron: CBS). Het lijkt er dus op dat de opvolgingssituatie in de IJsselmeervisserij iets gunstiger is in vergelijking met de landbouw. 


\subsection{Schepen}

Figuur 2.8 geeft een overzicht van het aantal IJsselmeerschepen, opgesplitst naar motorvermogen (kW-klassen), waarbij de kleinere schepen die als 'bijboot worden gebruikt, ( $<20 \mathrm{~kW}$ ) niet zijn inbegrepen (bron: NVR). Het merendeel valt in de categorie van 50 tot $100 \mathrm{~kW}$. Gemiddeld heeft de IJsselmeerkotter $138 \mathrm{~kW}$ (188 pk). Het gemiddelde casco is uit het jaar 1972 en dus gemiddeld bijna 50 jaar en daarmee zo goed als afgeschreven; na het jaar 2000 zijn er nog 4 nieuwe kotters bijgekomen (figuur 2.9). De gemiddelde motor stamt uit het jaar 1987; na 2000 zijn er op 7 kotters nog nieuwe motoren geïnstalleerd.

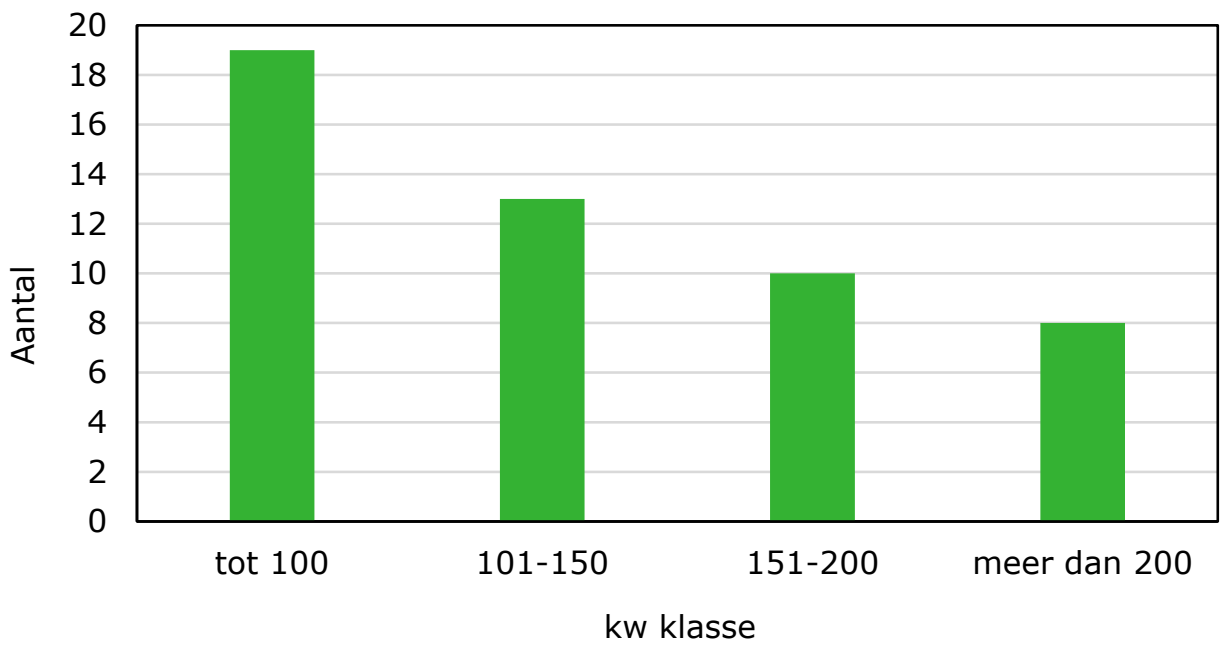

Figuur 2.8 Aantal IJsselmeerschepen per kW-klasse

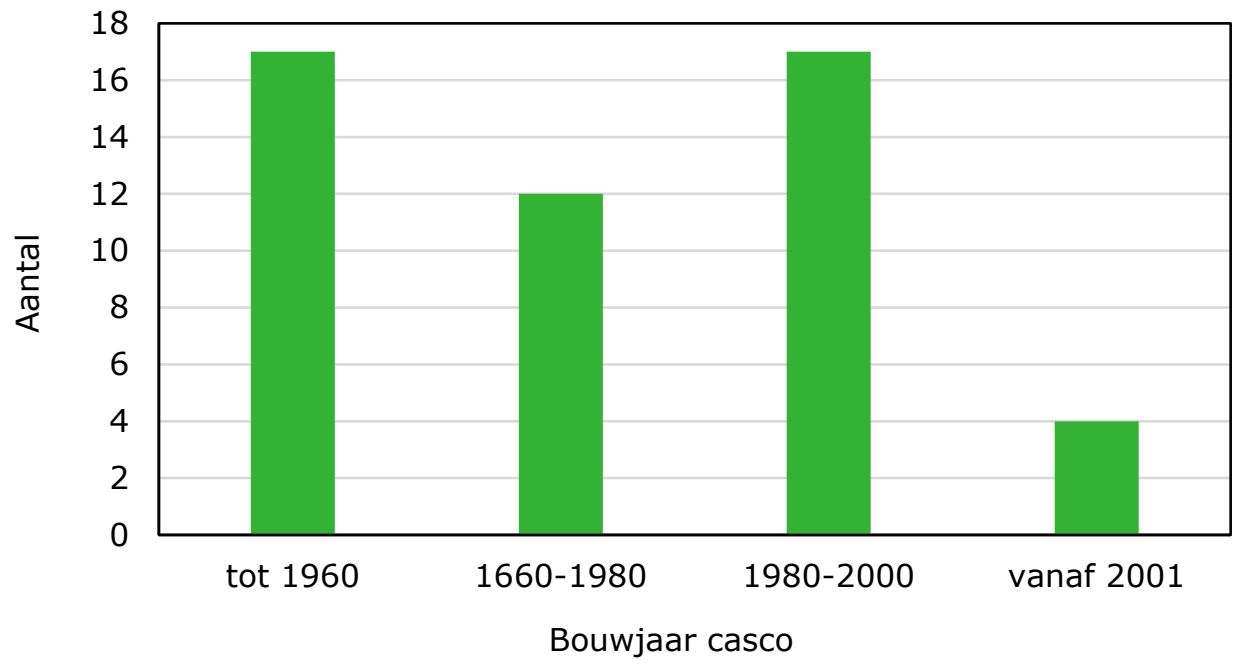

Figuur 2.9 Aantal kotters per bouwjaar 


\section{Waarde van visrechten en vistuigen}

\subsection{Aantallen merkjes en rechten}

Voor de waardebepaling van de verschillende vistuigen is het van belang inzicht te hebben in de aantallen beschikbare vistuigen en de vangsten per vistuig. De vangsten per vistuig zijn niet bekend, maar door het combineren van de verschillende gegevensbestanden is het mogelijk hiervoor een berekening te maken. Omdat aan elk vistuig een merkje met een nummer wordt toegekend, wordt ook wel gesproken over het aantal merkjes.

Tabel 3.1 geeft een overzicht van de aantallen beschikbare merkjes.

Tabel 3.1 Aantal uitgegeven merkjes (2020)

\begin{tabular}{lc} 
Vistuig (kleur merkje) & Uitgegeven merkjes \\
Grote fuik (geel) & 1.579 \\
\hline Schietfuik (groen) & 3.193 \\
\hline Aalkist (wit) & 7.415 \\
\hline Staand net hoog (zwart) & 623 \\
\hline Staand net laag (oranje) & 3.377 \\
\hline Hoekwant & 37 \\
\hline Zegen & 126 dagen \\
\hline Spieringfuik & 3.026 \\
\hline Bron: RVo. &
\end{tabular}

Uit gesprekken met vissers blijkt dat niet alle merkjes daadwerkelijk worden gebruikt of ingezet. Bedrijven met grote fuiken zetten bij voorbeeld niet altijd alle grote fuiken tegelijk uit, afhankelijk van de werkdruk en de te verwachten vangsten per fuik wordt soms een deel uitgezet. Aalkisten worden weinig meer gebruikt, dit vooral doordat er weinig tot geen aas (spiering) beschikbaar is en de vangsten tegenvallen. De lage netten staand want (oranje merkjes), bedoeld voor wolhandkrabvisserij, zijn weinig ingezet, omdat hiervoor een specifieke toestemming vanuit de Wet natuurbescherming (Wet-nb) noodzakelijk is. Om deze toestemming te verkrijgen, moet een kostbare passende beoordeling worden uitgevoerd. In gesprekken vertelden vissers dat de opbrengsten uit de wolhandkrabvisserij nauwelijks of niet konden opwegen tegen de kosten van vergunningverlening.

Verder is het in de maand juli niet toegestaan om gelijktijdig met netten te vissen in combinatie met fuiken. Vissers kunnen dan kiezen om òf voor de nettenvisserij òf voor de fuikenvisserij te gaan. Tenslotte zal ook door specifieke weersomstandigheden of bijzondere persoonlijke omstandigheden (bij voorbeeld ziekte) niet altijd gevist (kunnen) worden. Kortom: de inzet van vistuigen zal dus nooit $100 \%$ zijn.

Daarnaast is het mogelijk dat vissers vistuigen huren en verhuren van elkaar. Soms is de verhuur een inkomstenbron van vissers die nauwelijks nog actief zijn. In 2019 werden van de 126 beschikbare zegendagen nog 49 dagen verhuurd; van de 3.950 certificaten voor staande netten werd bijna $25 \%$ verhuurd (bron: RVO). Deze huur-/verhuurconstructies kunnen ervoor zorgen dat er een meer efficiënt gebruik van de vistuigen kan plaatsvinden. 


\subsection{Schubvistuigen}

Door de IJsselmeervissers worden sinds 2015 logboeken bijgehouden met betrekking tot de schubvisvangsten. Genoteerd worden de aantallen vistuigen, de tijdsduur in dagen, de datum waarop de vistuigen uitstaan en de bijbehorende vangsten per soort. De gegevens worden door WMR geanalyseerd. In 2015 en 2016 waren er opstartproblemen met deze registratie en ontbraken veel gegevens.

Uit een eigen (Wageningen Economic Research) analyse van de logboeken in vergelijking met de afslaggegevens van 2018 en 2019 blijkt dat van de totale brasemvangsten ongeveer een derde deel via de IJsselmeerafslag Urk wordt verkocht en van de baars-, snoekbaars- en voornvangsten ongeveer $85 \%$.

Figuur 3.1 geeft meer inzicht in de vangsten van schubvis naar vistuig (bron: logboeken, bewerking Wageningen Economic Research). Met staande netten wordt dus meer dan $90 \%$ van baars, voorn en snoekbaars gevangen. De zegen is een specifiek vistuig voor het vangen van brasem. In grote (aal)fuiken vindt nog een geringe bijvangst plaats van schubvis (zie tabel 3.2).

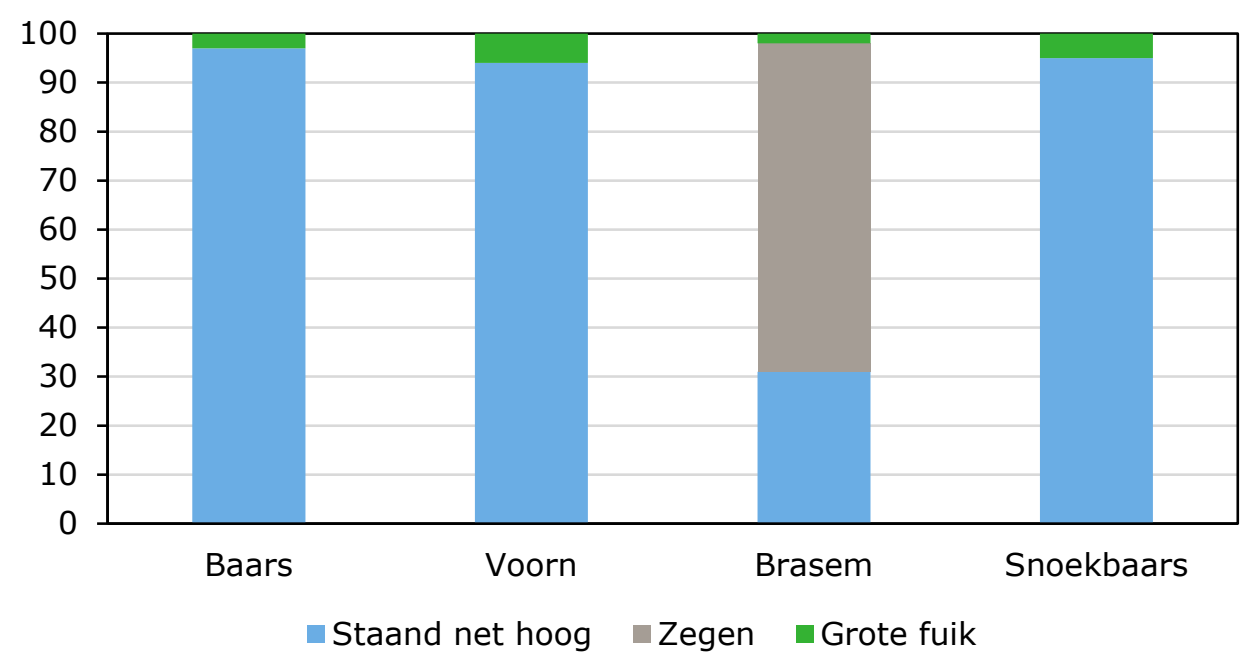

Figuur 3.1 Procentuele verdeling van de vangsten van schubvissoorten naar vistuig, 2017 tot en met 2019

\subsection{Aalvistuigen}

Met behulp van VIRIS aal (het logboeksysteem voor aalvangsten) is te achterhalen hoeveel aal er met de diverse aalvistuigen wordt gevangen. Figuur 3.2 geeft de procentuele verdeling weer, afgeleid van de VIRIS-gegevens van de jaren 2017 tot en met 2019. Voor het vangen van aal zijn dus vooral de grote fuiken van belang (48\%), gevolgd door schietfuiken (31\%), hoekwant (20\%) en aalkisten (1\%). 


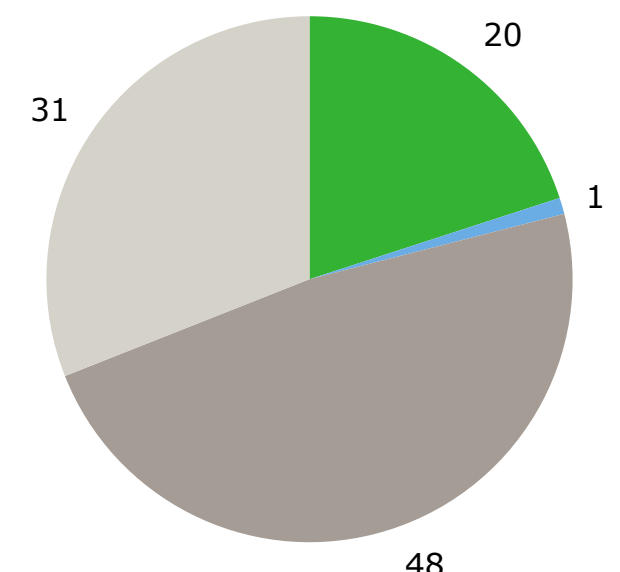

48

- Hoekwant Aalkisten Grote fuiken Schietfuiken

Figuur 3.2 Procentuele verdeling van de vangsten van aal naar vistuig (VIRIS, 2017 tot en met 2019)

\subsection{Totale vangsten per vistuig en warde per vistuig}

Door combinatie van de schubvisvangstverdeling en de aalvangstverdeling kan de totale vangst per vistuig worden berekend. Tabel 3.2 geeft de procentuele verdeling weer, gebaseerd op de registratiegegevens van de vissers (2017 tot en met 2019).

Tabel 3.2 Verdeling van de aanlandingen per vissoort naar vistuig (in procenten) op basis van vangstregistratie (2017-2019)

\begin{tabular}{lcrrrrrr} 
& Aal & Baars & Voorn & Brasem & Snoekbaars & Krab a) & Overig b) \\
Grote fuik & 48 & 3 & 6 & 1 & 5 & 80 & 10 \\
\hline Schietfuik & 31 & 0 & 0 & & 0 & 10 & \\
\hline Aalkist & 1 & & & & & & 5 \\
\hline Staand net hoog & & 97 & 94 & 32 & & 5 & 90 \\
\hline Staand net laag & 20 & & & & & & \\
\hline Hoekwant & & & & & & & \\
\hline Zegen & & &
\end{tabular}

a) Voor krab en de overige vissoorten is de verdeling over de vistuigen geschat, na consultatie met enkele vissers, WMR-onderzoekers en gebruik makend van gegevens uit de vorige studie (Zaalmink et al., 2017); b) De post overig is gering van omvang (0,5\% van totale vangsten) en bestaat uit snoek, blei en bot.

Uitgaande van de totale aantallen beschikbare vistuigen(/rechten), de totale jaarvangsten en de opbrengstprijzen kan een berekening worden gemaakt van de vangsten en opbrengsten per beschikbaar/uitgegeven recht. Hierna volgt een voorbeeld waarbij wordt uitgegaan van de gemiddelde jaarvangsten en prijzen over een langere periode (2015 tot en met 2019) zoals vermeld in tabel 3.3. 
Tabel 3.3 Gemiddelde aanlandingen, prijzen en besommingen van IJsselmeervis, gemiddeld over de periode 2015 tot en met 2019 (berekening Wageningen Economic Research)

\begin{tabular}{lrrr} 
Vissoort & kg & prijs/kg & opbrengst \\
Aal & 244.000 & 9,84 & 2.302 .000 \\
\hline Snoekbaars & 285.000 & 5,99 & 1.651 .000 \\
\hline Brasem & 139.000 & 1,45 a) & 161.000 \\
\hline Baars & 57.000 & 2,04 & 117.000 \\
\hline Voorn & 113.000 & 1,13 & 128.000 \\
\hline Krab & 52.000 & 16,47 & 844.000 \\
\hline Overig & 15.000 & 2,38 & 36.000 \\
\hline
\end{tabular}

a) inclusief opbrengst pootvis.

Tabel 3.4 geeft de gemiddelde vangsten weer per vergund vistuig, gebaseerd op de berekende vangsten volgens de methode van Wageningen Economic Research over de periode 2015 tot en met 2019. Tabel 3.5 geeft voor dezelfde periode de gemiddelde opbrengst weer per vergund vistuig.

Tabel 3.4 Gemiddelde vangst ( $\mathrm{kg}$ ) per vergund vistuig per jaar, 2015 tot en met 2019

\begin{tabular}{|c|c|c|c|c|c|c|c|}
\hline & Aal & Baars & Voorn & Brasem & Snoekbaars & Wolhandkrab & Diversen \\
\hline Grote fuik & 82 & 1 & 5 & 1 & 10 & 28 & 1 \\
\hline Schietfuik & 26 & 0 & 0 & 0 & 0 & 2 & 0 \\
\hline Staand net hoog & 0 & 95 & 196 & 73 & 490 & 5 & 23 \\
\hline Staand net laag & 0 & 0 & 0 & 0 & 0 & 56 & 0 \\
\hline Zegen & 0 & 0 & 0 & 754 & 0 & 0 & 0 \\
\hline
\end{tabular}

a) nihil.

Tabel 3.5 Gemiddelde opbrengst (euro) per vergund vistuig per jaar, 2015 tot en met 2019

\begin{tabular}{lr} 
Vistuig & Opbrengst (euro) \\
Grote fuik & 1.228 \\
\hline Schietfuik & 260 \\
\hline Aalkist & n.b. a) \\
\hline Staand net hoog & 25.243 \\
\hline Staand net laag & 856 \\
\hline Hoekwant & 12.985 \\
\hline Zegen & 8.149 \\
\hline
\end{tabular}

a) nihil.

Figuur 3.3 geeft het economische aandeel weer van de verschillende vistuigen in het totaal van de besomming uit het IJsselmeer (referentieperiode 2015 tot en met 2019). Staande netten maken hier $38 \%$ van uit, gevolgd door grote fuiken, schietfuiken, hoekwant en zegen. 


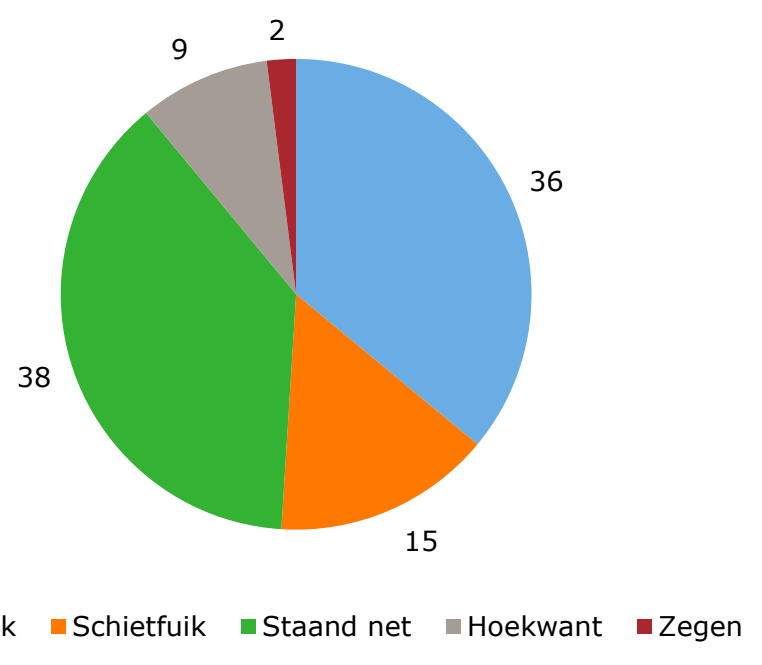

Figuur 3.3 Procentuele verdeling vistuigen naar totale besomming IJsselmeer, 2015-2019

\subsection{Waarde van rechten en kosten van vrijwillige uitkoop}

Voor de berekening van de waarde van rechten voor vistuigen en merken kan teruggegrepen worden op de economische waarde van de IJsselmeervisserij: de vangsten, de opbrengstprijzen en de beschikbare vistuigen en de inzet ervan. In Zaalmink et al. (2017) is de methodiek beschreven waarmee de waarde van rechten kan worden berekend. De berekeningen die hierna worden uitgevoerd, gaan uit van de vrije marktwaarde, dus de waarde in het handelsverkeer of bij vrijwillige uitkoop.

In het kort is de methodiek als volgt: uitgangspunt is de opbrengst (of besomming) per vistuig (type en aantal) per jaar. Voor de marktwaarde is het van belang om in te schatten wat er in de toekomst mee verdiend kan worden. Omdat de toekomst niet voorspelbaar is (vangsten en verdiensten) wordt vaak uitgegaan van resultaten uit het verleden, meestal een langere periode om toevalseffecten zoveel mogelijk uit te sluiten. In het hiernavolgende zullen verschillende periodelengtes in acht worden genomen, met name om de het effect te laten zien van het economisch resultaat op de berekende waarde van de verschillende vistuigen.

Uitgangspunt zijn de opbrengsten. De toegevoegde waarde is op basis van voorgaand onderzoek (Zaalmink et al., 2017) vastgesteld op 65\% van de totale opbrengst. Deze 65\% is dus in feite het inkomen van de ondernemer, en de overige $35 \%$ kan beschouwd worden als zijnde de kosten. Het is echter de vraag of bij toenemende opbrengsten de kosten evenredig zullen toenemen; met andere woorden, te verwachten is dat bij toenemende opbrengsten de kosten relatief minder zullen toenemen en dus de toegevoegde waarde meer zal toenemen. In deze studie is hier geen rekening mee gehouden, en is de toegevoegde waarde in alle situaties $65 \%$ van de opbrengst verondersteld.

Om te komen tot een vrije marktwaarde wordt de toegevoegde waarde vermenigvuldigd met een zgn. kapitalisatiefactor, bij vrijwillige verkoop is deze factor 5 . Dit gekapitaliseerde bedrag is de te verwachten verdienwaarde voor een periode van 5 jaar. Deze factor 5 is de factor waarmee wordt gerekend om te komen tot reële marktwaardes van rechten en is in het verleden getoetst voor de waarde van melk- en suikerquota (Zaalmink et al., 2016).

Deze berekeningsmethodiek is in dit hoofdstuk verder uitgewerkt in de tabellen 3.6 en 3.7. De berekende vrije marktwaardes zijn voor staande netten en zegen netten hoger dan die in de vorige studie zijn beschreven; dit komt door de veel hogere opbrengsten die de afgelopen jaren zijn behaald. Gezien voorgaande opmerking over de kosten zal de werkelijke vrije marktwaarde onder de genoemde veronderstellingen waarschijnlijk hoger zijn dan hier berekend. 
Tabel 3.6 Vrije marktwaarde van vistuigrechten/merken op basis van de periode 2015 tot en met 2019 a)

\begin{tabular}{llll} 
Vistuig & Opbrengst & Toegevoegde Waarde & Vrije marktwaarde \\
Certificaat voor staand net & 26.100 & 17.000 & 85.000 \\
\hline Zegen & 8.100 & 5.300 & 26.500 \\
\hline Grote fuik & 1.200 & 800 & 4.000 \\
\hline Schietfuik & 260 & 170 & 850 \\
\hline Hoekwant & 13.000 & 8.400 & 42.200 \\
\hline
\end{tabular}

a) spieringrechten en aalkistjes zijn buiten beschouwing gelaten omdat hier de laatste jaren niet or nauwelijks gebruik van gemaakt is. In een vorige studie is de vrij marktwaarde van een aalkist vastgesteld op 10 euro per kistje.

Tabel 3.7 Vrije marktwaarde (in euro) van vistuigrechten bij verschillende referentieperiodes

\begin{tabular}{lllll} 
Vistuig & $\begin{array}{l}2015 \text { tot en met } \\
2019\end{array}$ & $\begin{array}{l}2016 \text { tot en met } \\
2019\end{array}$ & 2017 tot en met & 2018 tot en met \\
\hline $\begin{array}{l}\text { Certificaat voor } \\
\text { staand net }\end{array}$ & 85.000 & 91.200 & 2019 & 105.600 \\
\hline Zegen & 26.500 & & 99.700 & 29.500 \\
\hline Grote fuik & 4.000 & 26.700 & 29.900 & 3.800 \\
\hline Schietfuik & 850 & 4.300 & 4.300 & 810 \\
\hline Hoekwant & 42.000 & 900 & 910 & 40.900 \\
\hline
\end{tabular}

Door de dalende aalprijzen nemen de waardes van de aalvistuigen in de laatste periode (2018 tot en met 2019) af. Door de gestegen snoekbaarsvangsten nemen de waardes van de schubvistuigen toe. Dit geeft aan dat de berekende waardes afhankelijk zijn van de behaalde resultaten in het verleden (vangsten en prijzen). 


\section{Herstructurering: mogelijkheden en kosten}

\subsection{Interesse uitkoopregeling}

Aan alle ondernemers is de vraag voorgelegd of er interesse is in een vrijwillige uitkoopregeling wanneer deze binnen één tot drie jaar van kracht zou zijn. Tabel 4.1 geeft meer inzicht in de mogelijke interesse in uitkoop van het bedrijf. Als er op korte termijn (1-3 jaar) een saneringsronde komt dan zijn er 7 vissers met in totaal 5 certificaten ofwel 250 netten (zwart en oranje samen) die hier gebruik van zouden willen maken. Hierbij zijn er 4 ondernemers/bedrijven die waarschijnlijk wel willen meedoen, mits er een redelijke vergoeding wordt betaald. Dit betreft ondernemers die financieel niet afhankelijk zijn van de visserij. Ze zijn of inactief, of vissen zelf niet veel, staan voor een duurzame IJsselmeervisserij en willen op dit moment hun vergunning niet aan collega's verkopen, bang dat ze zijn dat er intensiever gevist gaat worden.

Naast deze 4 bedrijven zijn er nog 3 bedrijven die mogelijk interesse hebben in uitkoop, mede afhankelijk van diverse factoren, zoals toekomstperspectief, eigen financiële situatie en de plannen voor het IJsselmeer en communicatie daarover door LNV. De geboden vergoeding vanuit de overheid is natuurlijk een belangrijke factor, maar emotie speelt ook een rol. Het betreft in alle gevallen bedrijven van oudere ondernemers zonder opvolger met een gemiddelde leeftijd van 63 jaar. Deze ondernemers zijn al generaties lang zeer nauw betrokken bij het IJsselmeer en nemen ook in overweging of een besluit goed is voor het IJsselmeer.

Daarnaast is gevraagd of er belangstelling zou zijn wanneer over een iets langere periode (10 jaar) een vrijwillige regeling van kracht zou kunnen zijn. Dan zijn er aanvullend nog 8 bedrijven die zeker of misschien interesse hebben in een uitkoopregeling. De meeste van deze bedrijven gebruiken nu hun rechten volledig en vissen jaarrond. In bijna alle gevallen betrof het bij de interesse in opkoop, bedrijven die geleid worden door ondernemers die gaan stoppen met werken omdat ze de pensioengerechtigde leeftijd hebben en er geen opvolger is. In enkele gevallen betreft het ondernemers die verder willen met de andere tak van hun bedrijf en zich dus meer willen specialiseren op handel of verkoop aan particulieren.

Tabel 4.1 Interesse in vrijwillige verkoop en bijbehorende kenmerken van de bedrijven

\begin{tabular}{|c|c|c|c|c|c|c|c|c|}
\hline Groep & Aantal & $\begin{array}{r}\text { Staande } \\
\text { netten }\end{array}$ & Zegen & $\begin{array}{r}\text { Spiering } \\
\text { fuiken }\end{array}$ & $\begin{array}{l}\text { Grote } \\
\text { fuiken }\end{array}$ & $\begin{array}{l}\text { Schiet } \\
\text { fuiken }\end{array}$ & $\begin{array}{l}\text { Hoek- } \\
\text { want }\end{array}$ & Aalkisten \\
\hline $\begin{array}{l}<3 \text { jaar zeer } \\
\text { waarschijnlijk }\end{array}$ & 4 & 100 & & & & 225 & 2 & 1.000 \\
\hline$<3$ jaar mogelijk & 3 & 150 & 1 & 225 & 80 & & 1 & 1.300 \\
\hline $\begin{array}{l}\text { 3-10 jaar zeer } \\
\text { waarschijnlijk }\end{array}$ & 3 & 150 & 2 & 150 & 50 & 30 & 2 & 0 \\
\hline 3-10 jaar mogelijk & 5 & 450 & 3 & 525 & 140 & 75 & 4 & 650 \\
\hline Totaal & 15 & 850 & 6 & 900 & 270 & 330 & 9 & 2.950 \\
\hline $\begin{array}{l}\text { Aandeel mogelijke } \\
\text { interesse ten opzichte } \\
\text { van totaal }(\%)\end{array}$ & 38 & 21 & 33 & 30 & 17 & 10 & 24 & 40 \\
\hline
\end{tabular}

De belangstelling voor vrijwillige uitkoop is gering. Het zijn de 'kleinere' bedrijven die mogelijk belangstelling hebben, waardoor bij uitkoop relatief minder visserijcapaciteit zal verdwijnen. In het algemeen kan gesteld worden dat de huidige groep vissers 'overlevers' zijn. Het vissen op het IJsselmeer is meer dan een inkomstenbron, het is ook een vanuit historie meegegeven levenswijze. Zij hebben periodes van slechte vangsten en mindere inkomsten overleefd door 'de tering naar de nering 
te zetten'. Diverse saneringsrondes zijn aan hun deur voorbijgegaan. Dit gecombineerd met het gegeven dat de laatste drie jaar goede jaren waren voor de IJsselmeervissers leidt dit tot een geringe belangstelling voor het laten opkopen van 'actieve rechten/visserijbedrijven'.

De afgelopen jaren is er goed betaald voor rechten en vergunningen om te vissen op het IJsselmeer. Veel huidige vissers hebben ondanks de hoge prijzen hun rechten niet verkocht. Er zijn zelfs enkele vissers die zeggen spijt te hebben van de rechten die ze in het verleden bij saneringsregelingen hebben ingeleverd.

Het is niet duidelijk hoe de markt van rechten en vergunningen zich gaat ontwikkelen in geval van een vrijwillige saneringsregeling. Enkele vissers hebben aangegeven niet te willen verkopen aan collega's, dit omdat ze de visserijdruk te hoog vinden. Zij zullen, wanneer de prijzen in de vrije markt gelijk zijn aan die van de saneringsregeling, de rechten bij voorkeur inleveren bij de regeling. Of dit daadwerkelijk zal gebeuren is natuurlijk ook afhankelijk van de marktconforme hoogte van de vergoeding.

\subsection{Kosten van vrijwillige uitkoop}

Tabel 4.2 geeft de (vrije markt) waarde weer van 2 groepen bedrijven: de groep die aangegeven heeft zeer waarschijnlijk of mogelijk op kortere termijn ( $<3$ jaar) gebruik te willen maken van een vrijwillige opkoopregeling en de groep die binnen een periode van 3-10 jaar hier zeer waarschijnlijk of mogelijk gebruik van zou willen maken. De vrije marktwaarde is gebaseerd op de aantallen rechten die de betrokken bedrijven in 2020 in bezit hebben en de marktwaarde per recht zoals in tabel 2.13 is weergegeven (basis periode 2015 tot en met 2019). In de tabel is daarbij onderscheid gemaakt tussen de vrije marktwaarde van schubvis vistuigen (staande netten en zegen) en aalvistuigen (grote fuiken, schietfuiken en hoekwant). Voor de 7 bedrijven in groep 1 gaat het dan om ruim $1,1 \mathrm{mln}$. euro en voor de 8 bedrijven in groep 2 om 2,4 mln. euro. Opgemerkt moet worden dat het gaat om een vrije marktwaarde, gebaseerd op prijzen en vangsten in de periode 2015 tot en met 2019, en dat wanneer een kortere meer recente periode genomen wordt als referentiebasis, de marktwaarde hoger zal zijn. Daar komt bij dat de werkelijke marktwaarde voor een ondernemer die wil kopen gebaseerd is op de verwachtingen in de toekomst, die altijd onzeker zijn.

Tabel 4.2 Vrije marktwaarde (uitkoopwaarde) van bedrijven die mogelijk binnen 3 jaar het bedrijf willen verkopen en van bedrijven die tussen drie en 10 jaar willen verkopen (gebaseerd op referentieperiode 2015 tot en met 2019)

\begin{tabular}{|c|c|c|c|}
\hline & Alle visserijbedrijven & $\begin{array}{l}\text { Bedrijven die binnen } \\
<3 \text { jaar willen stoppen }\end{array}$ & $\begin{array}{l}\text { Bedrijven die tussen 3- } \\
10 \text { jaar willen stoppen }\end{array}$ \\
\hline Aantal bedrijven & 39 & 7 & 8 \\
\hline Schubvisrechten (x 1.000 euro) & 7.263 & 451 & 1.150 \\
\hline waarvan staande netten ( $x 1.000$ euro) & 6.786 & & \\
\hline waarvan zegen (x 1.000 euro) & 477 & & \\
\hline Aalvisrechten ( $x 1.000$ euro) & 10.561 & 636 & 1.100 \\
\hline Totaal & 17.824 & 1.087 & 2.251 \\
\hline
\end{tabular}

a) exclusief waarde van spieringfuiken en aalkistjes.

Gebaseerd op de resultaten tijdens de periode 2015 tot en met 2019 bedraagt de totale vrije marktwaarde van de totale IJsselmeervisserij bijna $18 \mathrm{mln}$. euro. Bij de berekening van de marktwaarde van deze bedrijven is geen rekening gehouden met de eventuele waarde van aalkistjes en spieringrechten die nog in het bezit zijn van de vissers. Deze waarde is echter moeilijk vast te stellen.

Aalkistjes worden de laatste jaren heel weinig gebruikt door gebrek aan aas en doordat het een arbeidsintensieve visserij is. In de vorige studie uit 2017 is nog wel een waarde per aalkistje vastgesteld; deze zou toen 10 euro per kistje bedragen. Indien rekening wordt gehouden met deze 
waarde van aalkistjes wordt de totale marktwaarde van de groep die binnen 1 jaar wil verkopen verhoogd met 23.000 euro en de waarde van de tweede groep met 36.000 euro.

Spieringvisserij heeft sinds 2012 (inmiddels 8 jaar geleden) om wettelijke redenen niet meer plaatsgevonden. Op grond hiervan is het moeilijk voor de spieringvisserij een actuele economische waarde vast te stellen. Hebben spieringrechten waarde als deze visserij in de toekomst nooit meer zal worden toegestaan?

Verder is er nog de vraag of ook de $85 \%$ gereduceerde merkjes (oranje) nog toekomstige waarde hebben. De waarde die nu berekend is, is gebaseerd op één certificaat bestaande uit 50 merkjes, waarvan in de praktijk alleen $15 \%$ van de merkjes (zwarte) zijn gebruikt. De waarde van rechten in de (visserij)praktijk is wat de ondernemer denkt wat hij er in de toekomst mee kan verdienen. Vanuit de ondernemer redenerend gaat het om de volgende vragen/aspecten:

- Hoe groot is de kans dat ik in de toekomst op spiering mag vissen?

- En als dat zo is, hoeveel kan ik dan vangen en tegen welke prijs?

- En soms ook een beetje gokken: als een ander niet koopt en ik wel, en stel de visserij komt een keer los, dan kan ik in een keer een heleboel vangen en verdienen.

De kans dat er ooit een spieringvisserij terugkomt is heel gering. WMR concludeert dat in 2019 de spieringstand dramatisch laag is, dat spiering nodig is als voedsel voor onder andere snoekbaars (KRW) en voor vogels (Wet-nb).

In het rapport Overgangstermijn innemen ongebruikte rechten voor staande netten IJsselmeervisserij (Zaalmink et al., 2019) wordt onder andere geconcludeerd:

'Het innemen van een deel van de rechten voor staande netten heeft een zeer beperkte invloed op de eigendomswaarde van bedrijven en resterende rechten. Deze behouden hun economische waarde en daarmee ook de waarde bij verhandeling. Regulering van eigendom is toegestaan onder bepaalde voorwaarden. Eén van de voorwaarden is dat er een 'fair balance' moet zijn tussen het algemene belang en het individuele belang.

Daarom is in het algemeen een overgangstermijn noodzakelijk om ondernemers de gelegenheid te bieden de onderneming aan te passen aan de gewijzigde omstandigheden.

Bij het innemen van niet gebruikte rechten voor staande netten is een overgangstermijn van 5 tot 7 jaar tussen afkondiging en van kracht worden (ingaan) van een maatregel voldoende. Hierbij wordt geadviseerd om na deze overgangsperiode alleen die aantallen rechten in te nemen die tijdens deze periode niet meer toegestaan zijn.'

Vraag is of dit voor de spieringvisserij anders is. Waar de reductie van staande netten plaatsvond in het jaar 2014, heeft de spieringvisserij sinds 2012 niet meer plaatsgevonden. Met andere woorden: voor zowel de spieringfuiken als voor de $85 \%$ (oranje) staande netten kan er met vrij grote zekerheid van worden uitgegaan dat deze geen toekomstige waarde meer hebben.

\subsection{Mogelijkheden voor flankerend beleid}

Tijdens de gesprekken met vissers is ook gesproken over flankerend beleid: wat kan helpen om te besluiten de rechten te verkopen en voorgoed te stoppen met de visserij? Spontaan werden op deze vraag geen antwoorden gegeven, maar bij doorvragen kwamen de volgende punten naar voren:

- Men wil niet stoppen. De laatste jaren zijn er voldoende mogelijkheden geweest om tegen een goede prijs de rechten te verkopen. De vissers die wilden stoppen zijn al gestopt. Omdat voor de meesten vissen een levenswijze is wordt er niet aan gedacht om te stoppen met vissen en de rechten te verkopen.

- Fiscale aspecten. Men is bang dat bij bedrijfsbeëindiging een groot deel van de opbrengst naar de fiscus gaat. Een goede fiscale regeling zou eventueel kunnen helpen. 
- Opleidingsmogelijkheden. De vraag wat men zou willen doen als men geen visser zou (kunnen) zijn werd meestal beantwoord met een water gerelateerd beroep: zeevisserij, offshore, andere waterwerkzaamheden. Een enkeling gaf aan wel serieus na te denken of een aanvullende opleiding op dat gebied.

- Aanbod van water gerelateerd werk, zoals monitoring, waterplanten maaien, onderhoud van oevers, menstransport, educatie. Enkele Friese vissers vertelden zeer enthousiast over educatie activiteiten voor het basisonderwijs die ze enkele jaren geleden hadden verricht. Na het wegvallen van de subsidie hiervoor werden die activiteiten gestopt omdat het basisonderwijs dat zelf niet kon of wilde betalen. Conclusie was dat wanneer er een aanbod zou kunnen zijn van een grotere hoeveelheid jaarlijks werk, en dat er meerjarige contracten gesloten zou kunnen worden met continuïteitsperspectief men daar wel serieus over wilde nadenken.

- Er is geen interesse voor werk buiten de visserij. Omdat men de noodzaak ook niet voelt en ziet, is men zich er ook niet op aan het oriënteren.

Een enkeling doet soms wel tijdelijk werk buiten de visserij, maar met behoud van vergunningen en bijbehorende rechten. De mogelijkheid om weer te gaan vissen, willen deze vissers dan open houden.

Uit de gevoerde interviews blijkt dat de vissers weinig vertrouwen hebben in de noodzaak tot het komen van een herstructurering van de visserij. Zij zien zelf de vangsten en de visbestanden toenemen en begrijpen niet waarom ingrijpen noodzakelijk is. Er werden tijdens de interviews weinig andere stimulansen om te stoppen genoemd dan leeftijd en gebrek aan opvolging. Uit de gesprekken bleek dat een besluit om te stoppen vaak niet op basis van economische redenen wordt genomen maar veel meer door emotie.

Er zijn wel stimulansen denkbaar die tot minder visserij leiden. Een grote groep vissers heeft interesse in visserij gerelateerd werk, zoals het waterplanten maaien. Het vaartuig en de bemanning moet hiervoor geschikt zijn en er zal enige regelmaat of enig perspectief moeten zijn voor continuïteit hiervan. Ook het deelnemen aan (monitorings)onderzoek is een goed alternatief. De verwachting is dat niet de interesse, maar het aanbod de beperking zal zijn voor het uitvoeren van dit soort werkzaamheden. Verschillende vissers gaven namelijk aan dat ze zich hebben aangeboden voor uitvoering van dit werk, maar dat het niet nodig was.

\subsection{Aanvullende maatregelen voor visserijreductie en kosten ervan}

In de Kamerbrief Voortgang Actieplan toekomstbestendig visserijbeheer IJsselmeergebied

(6 oktober 2020) is aangegeven dat, mocht de vrijwillige regeling tot onvoldoende capaciteitsvermindering leiden, aanvullende maatregelen zullen worden ingesteld. Dit betreft een verlaging van de snoekbaarsvangsten tot maximaal 110 ton per jaar (met ingang van visseizoen 2023-2024), en een verbod op de zegenvisserij, dit laatste met ingang van visseizoen 2021.

De snoekbaarsvangsten kenden de afgelopen jaren een hoogtepunt met volgens de Wageningen Economic Research benadering 312 ton in 2018 en 521 ton in 2019. De gemiddelde opbrengstprijs van snoekbaars was 5,64 euro in 2018 en 5,17 euro in 2019. Het lijkt dat er een negatief verband is tussen de hoogte van de aanvoer van snoekbaars en de prijs van snoekbaars (zie tabellen 2.2 en 2.3). Mogelijk zal de prijs van snoekbaars hoger zijn wanneer minder snoekbaars wordt aangeland. Uit een loglineaire regressie blijkt dat op basis van de aanvoer en prijzen in de periode 2015 tot en met 2019 de prijs van snoekbaars bij een aanvoer van 110 ton 6,83 euro per kg zal zijn. Daarom wordt als voorbeeld een berekening uitgevoerd bij dit prijsniveau (tabel 4.3). 
Tabel 4.3 Berekende besommingsdervingen bij een snoekbaarsquotum van 100 ton per jaar

\begin{tabular}{lrrrrrr} 
& Basis & 2015 & 2016 & 2017 & 2018 & 2019 \\
Vangst/aanlanding (ton = 1.000 kg) & 110 & 142 & 225 & 512 & 5,61 \\
\hline Prijs ( $€ / \mathrm{kg}$ ) & 6,83 & 6,22 & 5,92 & 7,01 & 5,17 \\
\hline Besomming snoekbaars (x 1.000 euro) & 751 & 883 & 1.332 & 1.584 & 1.761 & 2.694 \\
\hline Verschil ten opzichte van basisscenario & 0 & 102 & 581 & 883 & 1.010 & 1.943
\end{tabular}

(x 1.000 euro)

Een vangstbeperking naar 110 ton snoekbaars per jaar zal leiden tot een jaarlijks totaal besommingsverlies van bijna 0,9 mln. euro vergeleken met de besomming in 2017 en ruim 1,9 mln. euro vergeleken met de besomming in het jaar 2019. Overigens werd in de voorgaande jaren 2013 en 2014 veel minder snoekbaars dan het voorgestelde quotum van 110 ton gevangen, nl. 36 ton in 2013 en 59 ton in 2014.

Van de 31 actieve bedrijven zijn er 10 gespecialiseerde schubvisbedrijven en 12 gemengde bedrijven met ook schubvisvisserij. In totaal zijn dit dus 22 bedrijven totaal met circa 44 vissers die afhankelijk zijn van de schubvisvisserij. Per 'gemiddelde' visser bedraagt bij een quotering van 110 ton snoekbaars per jaar het besommingsverlies circa 20.000 euro ten opzichte van 2017 en ten opzichte van 2019 circa 44.000 euro, waarbij de effecten tussen de vissers sterk kunnen verschillen door verschillen in de inzet van vistuigen en de vangsten per vistuig.

De zegenvisserij is vooral gericht op de vangst van pootvis met als meest belangrijke doelsoort brasem. Een verbod op de zegenvisserij betekent dus dat de pootvisvisserij wegvalt. De totale berekende opbrengsten uit de zegenvisserij wisselen sterk en variëren gedurende de periode van 2015 tot en met 2019 tussen 91.000 euro (2016) tot maximaal 184.000 euro (2018) per jaar. De gemiddelde zegen besomming over deze periode is 146.000 euro per jaar. De zegenvergunningen waren in 2019 in handen van 5 bedrijven met in totaal 13 vissers. De actieve zegenvisserij werd in 2019 uitgevoerd door 3 bedrijven. De brasembesomming is dus ongeveer 11.200 euro per gemiddelde visser. Een verbod op brasemvisserij zal dus voor deze 13 vissers een besommingsverlies van gemiddeld 11.200 euro per visser met een variatie van 7.000 euro per visser in 2016 tot 14.000 euro per visser in 2018 betekenen. Ook hier kunnen binnen hetzelfde jaar de effecten tussen vissers sterk verschillen afhankelijk van de inzet van de zegen en de gerealiseerde vangsten. 


\section{Discussie}

Dit onderzoek is uitgevoerd door onderzoekers die mede dankzij de gesprekken met vissers en andere betrokkenen de IJsselmeervisserij en alle betrokken partijen goed hebben leren kennen. Dit was mede noodzakelijk omdat de registraties en gegevens van vangsten en prijzen niet compleet zijn. Daardoor is het nodig om voor wolhandkrab en overige schubvis op basis van expert judgement gegevens te combineren en conclusies te trekken. Voor een exacter inzicht in de IJsselmeervisserij is een betrouwbare en complete registratie noodzakelijk. Hier zal de komende jaren aan gewerkt moeten worden.

De vrije marktwaarde van vistuigen is afhankelijk van de te verwachten verdiensten in de toekomst. Omdat we niet in de toekomst kunnen kijken, zijn de berekeningen gebaseerd op gegevens uit het verleden, waarbij verschillende termijnen zijn gebruikt, met name om inzicht te geven in de invloed van vangsten en prijzen op de marktwaarde. Dit kan leiden tot een verschil in wat de vissers als waarde zien van vistuigen en wat de berekende waarde is.

Aan alle vissers is gevraagd hoe zij de toekomst van hun eigen bedrijf zien. Dit is een momentopname en dit toekomstbeeld kan door persoonlijke en maatschappelijke ontwikkelingen veranderen. Wanneer er grote veranderingen zijn in bijvoorbeeld de prijzen, vangsten of overheidsbeleid, dan zal een visser zijn plannen bijstellen. Hiermee kan ook de behoefte aan flankerend beleid veranderen. Mocht het langer duren voordat het flankerend beleid wordt vastgesteld, is de aanbeveling om een korte enquête te houden om het beeld te actualiseren.

Ten tijde van de interviews met vissers bleek dat veel van wat de vissers vertelden over de plannen voor het IJsselmeer gebaseerd was op verhalen en conclusies van collega-vissers. Meerdere vissers hadden bij voorbeeld gehoord dat het advies van WMR (snoekbaarsquotum van 110 ton per jaar) zou leiden tot het mogen vissen met 2 van de 50 netjes. Door dit soort verhalen was er extra onrust bij de vissers. Wanneer deze verhalen leiden tot minder vertrouwen in de overheid dan zal de bereidheid om gezamenlijk te zoeken naar de beste vorm van herstructurering voor het IJsselmeer afnemen. Een zorgvuldige en complete communicatie vanuit alle betrokkenen is daarom van belang. 
1. De totale besommingswaarde van de IJsselmeervisserij is toegenomen van 2,9 mln. euro in 2014 tot 6,2 mln. euro in 2019. Deze hogere waarde wordt vooral veroorzaakt door hogere vangsten van snoekbaars en paling. Van deze besommingswaarde bestond in $201940 \%$ uit paling en $52 \%$ uit schubvis.

2. Staande netten en grote fuiken zijn economisch de meest belangrijke vistuigen voor het IJsselmeer. Samen zorgen zij voor 74\% van de totale besommingen. Dit wordt gevolgd door schietfuiken en hoekwant. Aalvistuigen zorgen samen voor $60 \%$ van de totale besomming, maar dit is inclusief de bijvangst van schubvis en wolhandkrab. De specifieke schuibvisvangsttuigen staand net en zegen hebben samen een aandeel van $40 \%$ van de totale besomming.

3. De vrije marktwaarde van vistuigen is afhankelijk van de te verwachten verdiensten in de toekomst. Wanneer wordt uitgegaan van gerealiseerde resultaten in het verleden dan is de waarde van de meest belangrijke vistuigen als in tabel 6.1 aangegeven.

Tabel 6.1 Vrije marktwaarde (in euro) van vistuigrechten bij verschillende referentieperiodes

\begin{tabular}{|c|c|c|c|c|}
\hline \multirow[t]{2}{*}{ Vistuig } & 2015 tot en met & 2016 tot en met & 2017 tot en met & 2018 tot en met \\
\hline & 2019 & 2019 & 2019 & 2019 \\
\hline Certificaat voor staand net & 85.000 & 91.200 & 99.700 & 105.600 \\
\hline Grote fuik & 4.000 & 4.300 & 4.300 & 3.800 \\
\hline Schietfuik & 850 & 900 & 910 & 810 \\
\hline
\end{tabular}

Deze waarde is berekend door de toegevoegde waarde bij gemiddelde vangsten en prijzen gedurende de genoemde periode van de vistuigen te nemen, en deze te vermenigvuldigen met een kapitalisatiefactor 5 .

4. Er zijn 39 IJsselmeervisserijbedrijven waarvan 31 bedrijven die voor het inkomen sterk afhankelijk zijn van de IJsselmeervisserij. De meeste bedrijven zijn één tot twee persoonsbedrijven maar er zijn ook grotere bedrijven met meer dan 3 vissers per bedrijf. Er zijn 10 gespecialiseerde schubvisbedrijven, 9 gespecialiseerde aalbedrijven en 12 gemengde bedrijven. In totaal zijn circa 63 gezinnen afhankelijk van de IJsselmeervisserij. Vier bedrijven hebben zich naast de visserij ook gespecialiseerd in de keten (handel en/of verwerking)

5. Op ongeveer een derde van de bedrijven is de visser ouder dan 50 jaar en is er geen opvolger beschikbaar. Ongeveer twee derde van de bedrijven heeft wel een opvolger of is de visser jonger dan 50 jaar. Deze vissers willen zeker de komende 15 jaar het bedrijf continueren. De opvolgingssituatie van de visserijbedrijven is iets beter in vergelijking met de landbouw.

6. Een achttal vissers maakt weinig of geen gebruik van de visrechten. Enkelen hebben de vergunning beroepsmatig nodig voor monitoringsactiviteiten. Het afstaan of verkopen van hun rechten vinden ze moeilijk, omdat ze er emotioneel geen afstand van kunnen doen (altijd in de familie geweest), of omdat ze nog als hobby de visserij uitoefenen, en/of als welkome aanvulling op de AOW.

7. De animo voor vrijwillig stoppen is gering. Vier ondernemers (vissers) geven aan serieus na te denken om binnen een jaar te stoppen als er een aantrekkelijke regeling komt en drie vissers zijn minder stellig maar willen er over nadenken. Daarnaast zijn er drie vissers die vanwege de leeftijd niet binnen één jaar, maar wel binnen 10 jaar zeer waarschijnlijk willen verkopen en vijf vissers die dit mogelijk willen doen. De bedrijven van deze vissers zijn gemiddeld kleiner van omvang dan de bedrijven die niet willen stoppen.

8. De vrije marktwaarde van de totale IJsselmeervisserij bedraagt circa $17,8 \mathrm{mln}$. euro, waarvan 7,3 mln. voor de schubvisrechten en 10,6 mln. voor de aalrechten. De vrije marktwaarde van die bedrijven die hebben aangegeven tussen nu en 10 jaar mogelijk gebruik te willen maken van een 
opkoopregeling is als volgt (gebaseerd op de economische waarde gedurende de periode 2015 tot en met 2019):

Tabel 6.2 Vrije marktwaarde (uitkoopwaarde) van bedrijven die mogelijk binnen 3 jaar het bedrijf willen verkopen en van bedrijven die tussen drie en 10 jaar willen verkopen (gebaseerd op referentieperiode 2015 tot en met 2019)

\begin{tabular}{|c|c|c|c|}
\hline & Alle bedrijven & $<3$ jaar & 3-10 jaar \\
\hline Aantal bedrijven & 39 & 7 & 8 \\
\hline Certificaten voor staande netten ( $\%$ van totaal) & & 6 & 15 \\
\hline Waarde schubvisrechten (x 1.000 euro) & 7.263 & 451 & 1.150 \\
\hline Waarde aalvisrechten (x 1.000 euro) & 10.561 & 636 & 1.100 \\
\hline
\end{tabular}

a) exclusief waarde van spieringfuiken en aalkistjes.

9. Vissers hebben over het algemeen weinig behoefte aan flankerend beleid. De volgende redenen werden genoemd:

- men wil niet stoppen. De huidige groep heeft in het verleden voldoende mogelijkheden gehad om de rechten te verkopen, heeft daar geen gebruik van gemaakt en is verknocht aan het bedrijf.

- fiscale aspecten. Men is bang dat bij bedrijfsbeëindiging een groot deel naar de fiscus gaat.

De volgende mogelijkheden voor (compenseren) flankerend beleid werden nog genoemd:

- aanbod van opleidingen. Een enkele visser noemde 'water' gerelateerde opleiding als mogelijkheid waar hij gebruik van zou willen maken.

- aanbod van 'water' gerelateerd werk. Als er zicht is op structureel en proportioneel werk op het IJsselmeer staat een aantal vissers daar wel voor open, en zou dat kunnen compenseren voor het inleveren van visrechten. Denk aan waterplanten maaien, visstandmonitoring, onderhoud van beschoeiingen, transport en dergelijke

10. De aanvullende maatregelen om de visserijdruk te verminderen zijn het mogelijk instellen van een maximale vangsthoeveelheid van snoekbaars van 110 ton per jaar en een verbod op de zegenvisserij. Een vangst van 110 ton snoekbaars betekent een aanzienlijke reductie van de vangsten ten opzichte van de laatste jaren. Per (schubvis)visser betekent dit een gemiddeld besommingsverlies van 18.000 euro ten opzichte van 2017 en 43.000 euro ten opzichte van 2019 . Een voorgenomen verbod op de zegenvisserij zal, berekend over de periode 2015 tot en met 2019 , gemiddeld op jaarbasis leiden tot een opbrengstderving van ruim 146.000 euro ofwel 11.200 euro per zegenvisser. 


\section{Literatuur en websites}

Kraal, M. Vissen op de zoete zee. Visionair nr. 54, december 2019.

Ministerie van LNV en I\&W (Rijkswaterstaat), PO IJsselmeer, Vogelbescherming Nederland, Sportvisserij Nederland Coalitie Blauwe Hart natuurlijk, provincies Fryslan, Flevoland en Noord Holland. Actieplan toekomstbestendig visserijbeheer IJsselmeergebied. Bijlage bij Kamerstukken II 2017/18, 31710, nr. 69, 8 maart 2019

Stichting Transitie IJsselmeer. Gedeeld Beeld Werkelijkheid IJsselmeervisserij. Een gemeenschappelijke feitenbasis over de ontwikkeling van de visstand en de visserij op het IJsselmeer en het Markermeer en de oorzaken hiervan. Oktober 2016.

Tien, N., I. Mosqueira Sanchez., T. Brunel, K. van der Hammen, K. Molla Gazi, K.S. van Donk, E. Foekema en J. de Leeuw. Bestandsoverzicht van snoekbaars, baars, blankvoorn en brasem en de evaluatie van potentiele oogstregels voor snoekbaars en baars in het IJssel/Markermeer 2020. Wageningen University \& Research rapport C041/20, april 2020.

Tien, N., T. Brunel, K.S. van Donk, E. Foekema en I. Mosqueira Sanchez. De evaluatie van potentiele oogstregels voor brasem en blankvoorn in het IJssel/Markermeer. Wageningen University \& Research rapport C070/20, juli, 2020.

Zaalmink, W., B. Janssens en H. Prins. Economische waarde IJsselmeervisserij. Notitie met betrekking tot de vaststelling van de waarde van vergunningen en merken. Wageningen Economic Research, Nota 2017-085, oktober 2017.

Zaalmink, W., H. Prins en B. Janssens. Overgangstermijn innemen ongebruikte rechten voor staande netten IJsselmeervisserij. Wageningen Economic Research, Nota 2019-006, januari 2019. 


\section{Bijlage 1 Gesprekslijst IJsselmeervissers}

\section{Introductie}

Hoe kijkt u tegen de toekomst van de IJsselmeervisserij aan?

Wat vindt $u$ het meest bedreigend op dit moment?

Zijn er ook nog kansen voor een perspectief volle visserij?

Mag ik straks daar verder op in gaan?

\section{Bedrijf}

Wat is de ligging? Waar vist u voornamelijk? Welke vistuigen zijn

belangrijk?

Wat voor type visserij hebt u vooral?

Omvang: aantal certificaten/merkjes staand net

Grote fuiken:

Locatie:

Schietfuiken:

Hoekwant:

Aalkistjes:

Zegenvisserij: ....dgn

Huurt of verhuurt u rechten van/aan anderen? Hoeveel en

waarom?

Hebt $u$ rechten aangekocht of verkocht en gaat $u$ dat ook in de

toekomst doen?

Gebruikt $u$ alle rechten altijd volledig of laat $u$ ze ook wel eens

onbenut? Zo ja, waarom en wanneer?

Hebt $u$ een eenmansbedrijf of met meerdere personen?

Werkt u ook samen met ander bedrijven, en zo ja op welke

manier?

Werkt uw partner ook mee, zo ja welke taken voert ze dan vooral

uit?

Hoe ziet uw arbeidsfilm er uit op uw bedrijf in de verschillende

periodes? Hoeveel uren maakt u gemiddeld voor het

visserijbedrijf?

Wat is de belangrijkste tak van het bedrijf: schubvis, aal, wolhandkrab:

....\% aal

....\% schubvis

....\% wolhandkrab

Hoe belangrijk is de zegenvisserij en waarom?

Bent $\mathrm{u}$ voor het inkomen afhankelijk van het bedrijf, of hebt $\mathrm{u}$ ook

$\ldots \%$ inkomen uit visserij

andere activiteiten waarmee verdiend wordt? In welke

verhouding?

Hoe is de verkoop van de vis geregeld? Is dit de afgelopen jaren veranderd?

$\ldots . . \%$ afslag

$\ldots \%$ rechtstreeks naar handelaar

$\ldots \%$ rechtstreeks naar consument

....\% na eigen verwerking

naar consument

Hoe heeft het bedrijf zich de afgelopen jaren ontwikkeld? Hoe is dat zo gekomen, wat zijn daarbij afwegingen geweest?

Welke investeringen zijn er de afgelopen vijf jaar gedaan en in welke orde van grootte?

Waarin is uw bedrijf nu sterk?

Wat kan nu worden verbeterd in het bedrijf? 
Hoe worden nu slechte jaren opgevangen?

Wat maakt het gemakkelijk om het bedrijf voort te zetten, wat werkt mee?

Wat maakt het moeilijk om het bedrijf voort te zetten, wat werkt tegen?

Hoe duurzaam is het bedrijf?

Economie

Natuur

Milieu

Maatschappelijk

Wat vindt u voor uw product belangrijk? strategie?
Klantenbetrokkenheid

Kostenbeheersing

Productleiderschap

Samenwerking met collega vissers

Samenwerking met andere partijen

Nieuwe activiteiten: zelf

vermarkten, andere

visserijen, andere diensten, buiten visserij

Specialiseren

Bedrijf verplaatsen

Groeien

Bewust krimpen

Afbouwen

Emigreren

Wait\&see

\section{Ondernemer}

Wat is uw leeftijd

Wat is uw gezinssituatie

Getrouwd/partner

Kinderen

Kinderen als opvolger

Is er een bedrijfsopvolger aanwezig, en zo ja wie?

$\mathrm{Ja} /$ nee/onbekend

Zoon/dochter/ander

familielid/ overig

Heeft u een specifieke opleiding genoten? En zo ja welke?

Heeft u nog wel eens behoefte aan een specifieke opleiding of

specifieke cursussen?

Wat vindt $u$ het mooiste aan uw beroep?

Waar wordt u vrolijk van?

Maakt u zich wel eens zorgen over de toekomst van uw bedrijf?

Waar ligt u vooral wakker van (als $u$ ergens wakker van wordt)

Hoe ziet u uw eigen toekomstbeeld?

Waar bent u vooral goed in, wat zijn uw sterke kanten?

Communiceren

(ondernemerschap, vakmanschap, menselijk)

Internationaal oriënteren

Leidinggeven

personeelsbeleid

Nieuwe kansen zoeken

Marktgericht zijn

Netwerken

Relatiebeheer

Omgevingsbewustzijn

Onderhandelen

Mening vormen

Organiseren 
Creativiteit

Overtuigen

Plannen

Probleemanalyse

Resultaatgerichtheid

Samenwerken

Strategisch denken

Visie uitdragen

Voortgang bewaken

Waardenbewustzijn

Zelfmanagement

Financieel inzicht

vakmanschap

Wat vindt u zelf belangrijk

Een boterham verdienen

Zelfstandig ondernemen

Eigen pensioen beheerder

Nieuwe producten

ontwikkelen

Anderen werk bieden

Bijdrage leveren aan de

maatschappij

.....

Waarin zou u zich kunnen verbeteren?

Waarin moet u zich vooral verbeteren om klaar te zijn voor de

toekomst?

Vindt $u$ dat $u$ voldoende gebruik maakt van de sterke kanten?

Wat zou u zijn geworden als u geen visserman was geworden?

\section{Omgeving}

Hoe kijkt u tegen de huidige ontwikkelingen op het IJsselmeer

aan?

ecologisch

economisch

maatschappelijke behoeftes

Natuur

Recreatie

Sportvisserij

Visstandbeheer

Wet- en regelgeving

Hoe belangrijk is de gemeenschap waarin u opereert van belang

voor u en uw bedrijf? Denk aan gezin, dorp, belangenorganisatie,

burgers enz.

Wie en welke organisaties zijn belangrijk voor de toekomst van

het IJsselmeer denkt u?

In welke zin hebben deze organisaties een positieve of

Hoe kijkt u tegen de markt aan van IJsselmeervis?

Toenemend

Afnemend

Niche/bulk

Zijn er mogelijkheden om de gevangen vis op een andere manier te vermarkten? Denkt u daarover na?

Ziet u ook mogelijkheden voor andere activiteiten op het water (multifunctioneel IJsselmeerondernemerschap) zoals waterplanten maaien, bestandsmonitoring, educatie, toerisme enz.

Hoe denkt u over krimp scenario's zoals:

verdere reductie staande netten 
verbod zegenvisserij

langere seizoenssluiting

grotere maaswijdtes

Welke mogelijkheden ziet $\mathrm{u}$ om selectiever te gaan vissen?

Als $u$ advies nodig hebt voor/over uw bedrijf, bij wie kunt u dan

terecht?

\section{Overig}

Welke kansen ziet u voor de toekomst?

Hoe ziet u het IJsselmeer in 2040 (over één generatie)?

Voor hoeveel bedrijven is er dan plaats en hoe zien die bedrijven

er dan uit?

Hoe ziet u de toekomst van uw bedrijf dan?

Wat zou er nu dan moeten gebeuren om dat te realiseren?

Wat zou er gebeuren als de overheid niet reguleert?

Welke mogelijkheden zijn er om te innoveren? Bijvoorbeeld

selectiever vissen, gegevensverzameling, multi purpose

ondernemerschap, 'stille' kotters, producten anders in de markt

zetten enz.

Zou u willen blijven vissen, en waarom wel of waarom niet?

Denkt $u$ er wel eens over om te stoppen? En waarom

Hebt u alternatieven voor de visserij? Stel u zou moeten stoppen

wat zou u dan doen?

Wat gebeurt er als u stopt, wat zijn dan uw zorgen?

Wat heeft u nodig om te gaan stoppen? Gaat het om geld, om subsidie, om bijscholing, om nog iets anders?

Is er ook behoefte aan een kenniscentrum IJsselmeervisserij?

Bedoeld voor vissers, hengelaars, natuurontwikkelaars, burgers, consumenten enz. Hoe zou dit vorm moeten krijgen?

Wat zou u ons nog willen meegeven wat niet aan de orde is geweest? 
Wageningen Economic Research Postbus 29703

2502 LS Den Haag

T 0703358330

Ecommunications.ssg@wur.nl

www.wur.nl/economic-research

Wageningen Economic Research RAPPORT

2021-029
De missie van Wageningen University \& Research is 'To explore the potential of nature to improve the quality of life'. Binnen Wageningen University \& Research bundelen Wageningen University en gespecialiseerde onderzoeksinstituten van Stichting Wageningen Research hun krachten om bij te dragen aan de oplossing van belangrijke vragen in het domein van gezonde voeding en leefomgeving. Met ongeveer 30 vestigingen, 6.500 medewerkers ( $5.500 \mathrm{fte})$ en 12.500 studenten behoort Wageningen University \& Research wereldwijd tot de aansprekende kennisinstellingen binnen haar domein. De integrale benadering van de vraagstukken en de samenwerking tussen verschillende disciplines vormen het hart van de unieke Wageningen aanpak.

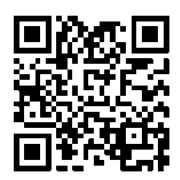





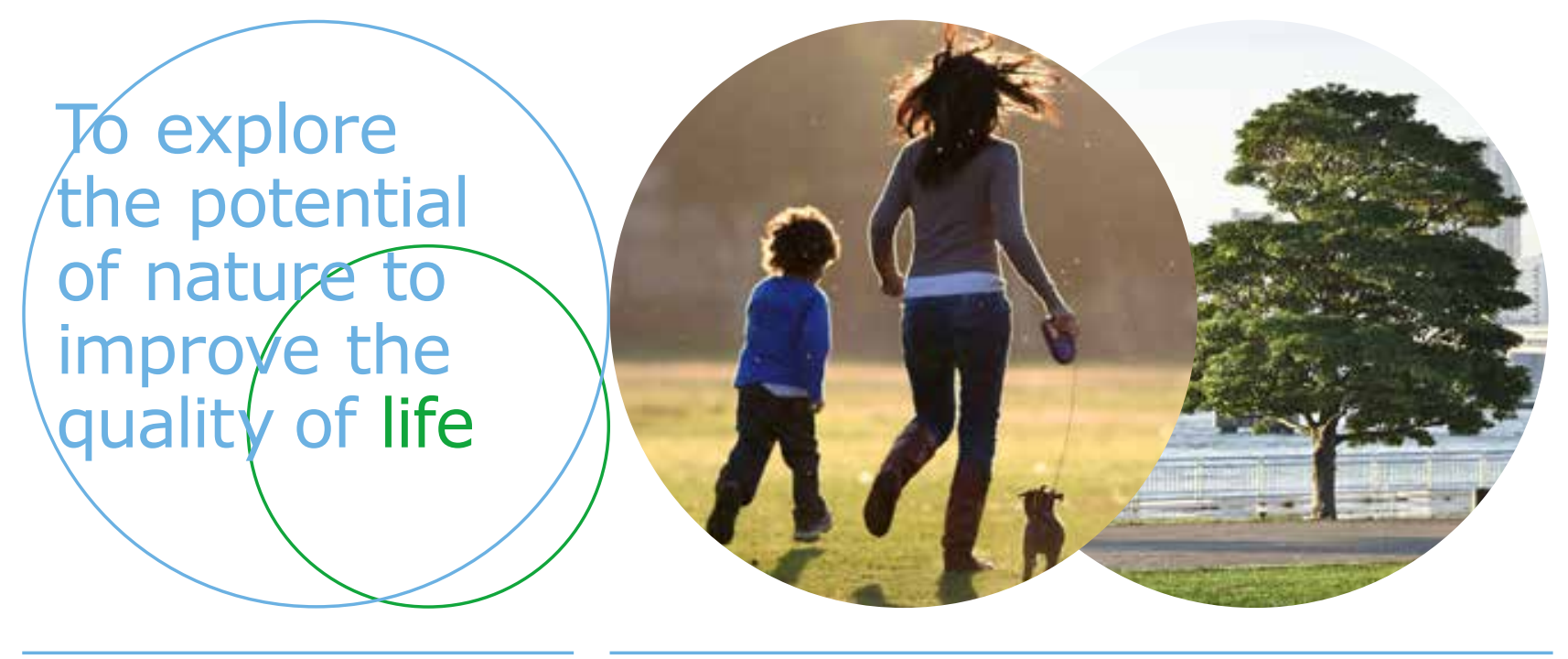

Wageningen Economic Research Postbus 29703

2502 LS Den Haag

T 0703358330

E communications.ssg@wur.nl www.wur.nl/economic-research

Rapport 2021-029

ISBN 978-94-6395-742-7
De missie van Wageningen University \& Research is 'To explore the potential of nature to improve the quality of life'. Binnen Wageningen University \& Research bundelen Wageningen University en gespecialiseerde onderzoeksinstituten van Stichting Wageningen Research hun krachten om bij te dragen aan de oplossing van belangrijke vragen in het domein van gezonde voeding en leefomgeving. Met ongeveer 30 vestigingen, 6.500 medewerkers ( $5.500 \mathrm{fte}$ ) en 12.500 studenten behoort Wageningen University \& Research wereldwijd tot de aansprekende kennisinstellingen binnen haar domein. De integrale benadering van de vraagstukken en de samenwerking tussen verschillende disciplines vormen het hart van de unieke Wageningen aanpak. 